\title{
Using Research to Support Transformative Impacts on Complex, "Wicked Problems" With Pastoral Peoples in Rangelands
}

OPEN ACCESS

Edited by: Fred Provenza

Utah State University, United States

Reviewed by:

Nathan Sayre,

University of California, Berkeley, United States

Durgesh K. Jaiswal,

Banaras Hindu University, India

*Correspondence:

Robin S. Reid

robin.reid@colostate.edu

Specialty section:

This article was submitted to Agroecology and Ecosystem Services, a section of the journal Frontiers in Sustainable Food Systems

Received: 30 August 2020 Accepted: 26 November 2020 Published: 18 January 2021

Citation:

Reid RS, Fernández-Giménez ME, Wilmer $H$, Pickering T, Kassam K-AS,

Yasin A, Porensky LM, Derner JD, Nkedianye $D$, Jamsranjav $C$, Jamiyansharav $K$, Ulambayar $T$,

Oteros-Rozas E, Ravera F,

Bulbulshoev U, Kaziev DS and Knapp CN (2021) Using Research to Support Transformative Impacts on Complex, "Wicked Problems" With

Pastoral Peoples in Rangelands. Front. Sustain. Food Syst. 4:600689. doi: 10.3389/fsufs.2020.600689

\begin{abstract}
Robin S. Reid ${ }^{1 *}$, María E. Fernández-Giménez ${ }^{2}$, Hailey Wilmer ${ }^{3}$, Tomas Pickering ${ }^{4}$, Karim-Aly S. Kassam ${ }^{5}$, Apin Yasin ${ }^{6}$, Lauren M. Porensky ${ }^{7}$, Justin D. Derner ${ }^{8}$, David Nkedianye ${ }^{9}$, Chantsallkham Jamsranjav ${ }^{2}$, Khishigbayar Jamiyansharav ${ }^{10}$, Tungalag Ulambayar ${ }^{11}$, Elisa Oteros-Rozas ${ }^{12}$, Federica Ravera ${ }^{12}$, Umed Bulbulshoev ${ }^{13}$, Daler S. Kaziev ${ }^{5}$ and Corrine N. Knapp ${ }^{14}$

${ }^{1}$ Department of Ecosystem Science and Sustainability, Colorado State University, Fort Collins, CO, United States, ${ }^{2}$ Department of Forest and Rangeland Stewardship, Colorado State University, Fort Collins, CO, United States, ${ }^{3}$ United States Department of Agriculture Forest Service Pacific Northwest Research Station, Juneau, AK, United States, ${ }^{4}$ Graduate Degree Program in Ecology, Colorado State University, Fort Collins, CO, United States, ${ }^{5}$ Department of Natural Resources \& the Environment, and the American Indian \& Indigenous Studies Program, Cornell University, Ithaca, NY, United States, ${ }^{6}$ Samburu Youth Education Fund, Archer's Post, Kenya, ${ }^{7}$ United States Department of Agriculture Agricultural Research Service, Fort Collins, CO, United States, ${ }^{8}$ United States Department of Agriculture Agricultural Research Service, Cheyenne, WY, United States, ${ }^{9}$ Independent Researcher, Athi River, Kenya, ${ }^{10}$ Center for Environmental Management Military Lands, Colorado State University, Fort Collins, CO, United States, "Zoological Society of London, Ulaanbaatar, Mongolia, ${ }^{12}$ Chair on Agroecology and Food Systems, University of Vic - University of Central Catalonia, Barcelona, Spain, ${ }^{13}$ Public Foundation CAMP Tabiat, Khorog, Tajikistan, ${ }^{14}$ Haub School of Environment and Natural Resources, University of Wyoming, Laramie, WY, United States
\end{abstract}

Pastoralists and researchers (and others) are finding new ways of working together worldwide, attempting to sustain pastoral livelihoods and rangelands in the face of rapid and profound changes driven by globalization, growing consumption, land-use change, and climate change. They are doing this partly because of a greater need to address increasing complex or "wicked" problems, but also because local pastoral voices (and sometimes science) still have little impact on decision-making in the governmental and private sectors. We describe here, using six worldwide cases, how collaborative rangelands partnerships are transforming how we learn about rangelands and pastoralists, whose knowledge gets considered, how science can support societal action, and even our fundamental model of how science gets done. Over the long-term, collaborative partnerships are transforming social-ecological systems by implementing processes like building collaborative relationships, co-production/co-generation of knowledge, integration of knowledges, social learning, capacity building, networking and implementing action. These processes are changing mental models and paradigms, creating strong and effective leaders, changing power relations, providing more robust understanding of rangeland systems, reducing polarization and supporting the implementation of new practices and policies. Collaborative partnerships have recurring challenges and much work is yet to be done. These challenges rest on the enduring complexity of social-ecological problems in rangelands. At a practical level, partnerships struggle with listening, amplifying and partnering with diverse (and sometimes marginalized) voices, the time commitment needed to make partnerships 
work, the bias and naivete of scientists, the recognition that partnerships can promote negative transformations, management of power relations within the partnership, and the need to attribute impacts to partnership activities. We think that the future of this work will have more focus on systems transformations, morals and ethics, intangible and longterm impacts, critical self-assessment, paradigm shifts and mental models, and power. Overall, we conclude that these partnerships are transformative in unexpected and sometimes intangible ways. Key transformations include changing mental models and building the next generation of transformative leaders. Just as important is serendipity, where participants in partnerships take advantage of new windows of opportunity to change policy or create new governance institutions. We also conclude that collaborative partnerships are changing how we do science, creating new and transformative ways that science and society interact that could be called "transformative science with society."

Keywords: transformations, social-ecological systems, social learning, pastoralist, collaborative partnerships, co-generation of knowledge

\section{INTRODUCTION}

A recent global assessment (IPBES, 2019) led to the logical conclusion that achievement of global equity and sustainability requires rapid change. It is not enough to make incremental, adaptive change; rather, we need transformational change with rapid leaps to a new normal (O'Brien, 2012; Moore et al., 2014; DĨaz et al., 2019). Here, a "transformation" is a change process that creates a fundamental change in the purpose, structure, form or function of our social, economic or ecological systems (Walker et al., 2004; Moser, 2016).

These transformations can be deliberate or unintended (O'Brien, 2012), initiated by governments, civil society, the private sector, citizens or others. They can also be driven by natural disasters, abrupt climate change or other system changes. Deliberate transformations occur because the existing system is no longer tenable (Walker et al., 2004). This may mean transforming how we lead, how we learn, the way our institutions work, and how we think about nature and society (Pennington et al., 2013; Abson et al., 2017). It also means creating innovative, adaptive, inclusive, just and equitable governance approaches (DĨaz et al., 2019); promoting the use of social innovations and social entrepreneurs (Westley et al., 2006, 2017; Biggs et al., 2010); strongly respecting and combining different knowledges (Agrawal, 1995; Berkes, 1999; Max-Neef, 2005; Tengo et al., 2014; Mistry and Berardi, 2016); and integrating across systems, jurisdictions and tools (DĨaz et al., 2019). Scholarship on transformation has typically focused on understanding the external process of transformation (Olsson et al., 2006), rather than the mechanisms that lead to internal changes, which have been proposed to be more durable and impactful (Meadows, 1999; Abson et al., 2017).

When scholars and practitioners describe rangelands, they describe multiple transformations, both deliberate and unintended. A common deliberate transformation is a change in land tenure from the pastoral commons to either public conservation land (like parks) or to private land (Galvin, 2009; Herrick et al., 2012; Reid et al., 2014a). Transformations also consist of changes in land use from pastoralism to extractive industries, cropland, and exurban development or shifts from family-run ranches to ranches run by absentee owners (Fernández-Giménez, 1999a; Gosnell et al., 2006). Or they involve the shift from state-owned livestock to privately owned livestock with the fall of communism in central Asia while, in some instances, expanding unsustainable herd sizes (e.g., Fernández-Giménez, 1999b; Kerven, 2003). Clearly transformations can be either positive or negative depending on your values and worldview. Rangeland scientists often study these transformations in state-and-transition models, which describe how the linked social-ecological system can shift from one state to another through transition processes (Briske et al., 2005). Unintended transformations include the loss of grassland productivity due to climate change (e.g., Bruegger et al., 2014) and shifts in pastoralism caused by drought and winter storms (e.g., Fernández-Giménez et al., 2015).

Another deliberate transformation, aimed at positive transformations from a pastoral worldview, are those driven by rangelands partnerships. Diverse and collaborative partnerships involve participants with different values, incentives, priorities and knowledges, like Indigenous peoples, ranchers, pastoralists, government managers, conservation practitioners and researchers. Partnerships form to achieve a particular goal (O’Brien, 2012) within a particular grazing social-ecological system. Rangeland partnerships learn together and forge new solutions to problems they identify for particular places. In the process, they transform the participants, reducing polarization and creating "face-to-face" democracy (Brick et al., 2001; Conley and Moote, 2001; Knight and White, 2009; Knight, 2010). For example, the Blackfoot Challenge and the Malpai Borderlands are two rancher-led partnerships in the US that formed to prevent further fragmentation of open, rural landscapes and to address the loss of biodiversity caused by woody plant encroachment 
on grasslands (McDonald, 2002; Charnley et al., 2014; Wilson et al., 2017; Belsky and Barton, 2018). These alliances have been called "strange bedfellows" or "unlikely," alluding to partnerships of diverse participants who have historically been at odds, like ranchers and environmentalists (Hillis et al., 2020). In Africa and Asia, these are often called community-based natural resource (or rangeland) management initiatives (Dressler et al., 2010; Shackleton et al., 2010) or, more broadly, community conservation initiatives. These community-based partnerships are important because rural communities and Indigenous Peoples use and manage over half of the Earth's land collectively under community-based, customary ownership systems (Alden Wiley, 2011).

Some of these collaborative partnerships not only attempt to transform pastoral systems in a positive manner, but they also aim to transform how scientists work with pastoral peoples. They attempt to create science that meets the needs of pastoral peoples and the rangelands they depend upon. These diverse, problem-solving partnerships span the boundaries between science/research and practice/action (Lang et al., 2012). Scientists often play diverse roles like the reflective scientist, intermediary and facilitator in these joint learning processes (Pohl et al., 2010). Both in rangelands and elsewhere, these partnerships have created outputs, outcomes and impacts including useful products, relevant knowledge, increased decision-making capacity, deeper or wider networks, and transformational changes like economic benefits, decisions made and new organizations or policies established (Walter et al., 2007; Wiek et al., 2014).

This transformation in the way social-ecological science is done through collaborative partnerships is nested within a much broader change in science. In the last few decades, the part of science that focuses on societal problems has been quietly transforming into a whole new science (Klein, 2009; Knapp et al., 2019) in two principal ways (Hadorn et al., 2006; Lang et al., 2012; Cornell et al., 2013). First, scientists increasingly seek to understand complex (often called "wicked") problems using knowledge from several disparate disciplines. Most scientists are still trained in a single discipline and thus integrating two or more disciplines into interdisciplinary science (like ecology and anthropology) is rare and difficult to do well (Klein, 2009). Second, if scientists want their understanding of wicked problems to support broader society to solve those problems, scientists often have to work directly and collaboratively with other members of society, to co-generate knowledge, learn together and then experiment with implementing that new knowledge in on-the-ground action (called transdisciplinary science or science with society). We propose here that transdisciplinary science is evolving into a new science which focuses more on epistemologies (different ways of knowing, not just different knowledges), power, action and transformation of systems.

These collaborative partnerships of science with society are addressing another age-old problem: science is often not used by decision makers when addressing large scale and complex societal issues (Meffe et al., 2006; van Kerkhoff and Lebel, 2006; McNie, 2007; Reyers et al., 2010; O’Brien, 2013; van Kerkhoff, 2014). This "science-action gap" still exists even in areas of science that explicitly focus on applied societal problems like land degradation, biodiversity loss, climate change, food security, conservation, pandemic disease, and poverty. This gap exists because of high problem complexity, compartmentalization of knowledge and poor (or limited) collaboration between decision makers and scientists (Max-Neef, 2005; Hadorn et al., 2006). We think it also exists because decisions are ultimately made to benefit people who hold power and not all scientific results provide those benefits.

This evolution in science through partnership with society has a long history of thought and practice within the social sciences, medicine, health and, more recently, the biophysical sciences (Miller and Wyborn, 2018; Knapp et al., 2019). In different disciplines, this approach has diverse names with diverse definitions, including applied research, research with action, knowledge with action, science with society, transdisciplinary research with action, transdisciplinary research or science, public participation in science, translational science, Indigenous knowledge and science, collaborative adaptive management, sustainability science, civic science, post-normal science or Mode-2 research (Seidl et al., 2013; Knapp et al., 2019; Wyborn et al., 2019).

Today, these partnerships flourish in many ecosystems and work on a wide diversity of problems with some led by scientists and others by actors/practitioners (Chambers et al., in review). They often struggle to put science and action goals on equal footing (Reid et al., 2016a), to balance power dynamics among different participants (Schuttenberg and Guth, 2015; Miller and Wyborn, 2018; Knapp et al., 2019) and to adapt to changing issue dynamics over time (Mauser et al., 2013). A global analysis of 32 partnerships, primarily led by researchers, showed they had a wide variety of intended and achieved outcomes including knowledge production, knowledge transfer, capacity building, building networks, process learning, process quality, reframing the problem, empowerment, social equitability, institution building, policy uptake, management practices, and ecological and social outcomes (Chambers et al., in review).

Here we focus on what we will call science with society (SWS) partnerships in rangelands. Grazing in rangelands by wildlife and livestock herded by pastoral peoples is the most widespread way that humans use land (Asner et al., 2004) partly because rangelands cover $25-40 \%$ of the Earth's land surface (Asner et al., 2004; Reid et al., 2014a). Rangelands are also particularly marginalized, ecologically, economically and politically (Sayre et al., 2013). Rangelands may be extensive but per hectare productivity is low and pastoral peoples are widely dispersed and far from centers of power (Reynolds et al., 2007; Cleaver, 2012; Sayre et al., 2013). Pastoralists most often live in common land and thus often have weak ownership and decision making power over their lands (Reid et al., 2014a). With sparse populations and weak tenure, pastoral peoples are more subject to competition with other land uses. Pastoral land is also sometimes subjected to "land grabbing" by governments for conservation areas or commercial uses, and by farmers for crop cultivation (Abbink, 2011; Borras and Franco, 2012). 
We suspect that collaborative partnerships may be particularly innovative, needed and impactful in rangelands, embedded in pastoral society. Why? Pastoralists, like many rural peoples around the world, must innovate with what they have at hand (or bricolage), partly because markets and centers of power are often far away. Thus research, if driven by pastoral needs, becomes part of that bricolage. Also, since pastoralists are marginalized and often have weak land tenure, they may engage in partnerships as a way to strengthen their voices with powerful government and private sector actors through the power of science and expertise.

On the research side in these partnerships, two patterns are evident. In our experience, pastoral scholars are strongly devoted to pastoralism and thus have the stamina and persistence to be part of these time-consuming partnerships. And, while this inclusive partnership approach is unfolding across the globe in many systems, it is especially needed in rangeland systems. Rangeland systems often support marginalized communities, thus SWS partnerships can be designed to highlight pastoral voices. Pastoralists and ranchers face similar challenges around the globe (Reid et al., 2014a; Espeland et al., 2020) and thus significant learning across sites is possible. Rangelands also are understudied; publications in the last few decades including the keyword, "rangelands," are about $2-3 \%$ of the number of publications that included the keywords, "farm," "forest," "marine," or "urban"1. More research, particularly aimed at information that local stakeholders need, could help fill this gap.

Here, we will briefly summarize our evolving science and SWS partnerships in rangeland systems. We will focus on if and how these partnerships support transformative action toward more sustainable rangeland systems. In this paper, we have three objectives:

1. To describe a set of cases of partnerships representing a diversity of approaches to developing and implementing integrated teams of pastoralists/ranchers and researchers, which are addressing critical issues in social-ecological rangeland systems.

2. To focus on the outcomes, impacts and impact pathways of these cases and then to assess whether these are and are not transformative, and if so, how.

3. To look into the future to the next evolution of science with society.

We will start by describing our case development methods, the six cases and a comparative case framework. We will then use our cases to exemplify key definitions, concepts and processes involved in these partnerships.

\section{CASE DEVELOPMENT METHODS}

The cases below were developed by the senior author based on literature, written and oral interviews and emails with the co-authors of this paper. The cases were not designed to be comparable with a common model and thus we base this analysis

\footnotetext{
${ }^{1}$ Our search of the Web of Science database on 30 June 2020 of the number of papers written in about the last 3 decades including the keywords of rangeland compared to papers using keywords of farm, forest, urban, marine.
}

on logic and synthesis. The literature and other documents, interview transcripts, notes and emails were used to create a matrix of characteristics for the cases, with selected parts of that matrix summarized as Table 1 (below). The lead author designed the matrix around top-level codes developed from the above information. The top-level codes arose partly from the literature and partly inductively from the cases and are the same across all the cases. Within those top-level codes are sub-codes (or lower level codes) in the cells in Table $\mathbf{1}$ and these vary from case to case and thus form the basis for our case comparisons along with contrasting secondary data describing the cases from other documents. In the text, we use selected illustrative quotes to demonstrate key points. All authors read and approved the following descriptions of their partnerships.

\section{OUR CASES AND THEIR CONTRASTING APPROACHES}

\section{Case Descriptions and the Theoretical Basis for Each Partnership Approach CARM Project, Colorado (Wilmer Interview)}

The Collaborative Adaptive Rangeland Management (CARM) project started in 2012 as a large, 10-year, ranch-scale participatory grazing experiment. A group of stakeholders and scientists co-created ways to manage the land in the semi-arid shortgrass steppe "to pass it on to future generations economically and ecologically." The partnership team consisted of "government agencies, conservation non-governmental organizations, ranchers, and interdisciplinary researchers" (Wilmer et al., 2018). The team's goal was to intensively experiment with contrasting grazing practices and then adapt as they learned. The problem of focus originated with the researchers but was of strong interest to the Crow Valley Livestock Cooperative, the local grazing association, as well. The partnership encountered disorienting dilemmas (see Figure 2 below) in their intensive reflection and learning process and struggled with emergent complexities and trade-offs between grassland bird habitat and beef production (FernándezGiménez et al., 2019b). They used processes like reflection, co-production/co- generation of knowledge and evaluation of outcomes that resulted in changing mental models and epistemologies, and social learning. Their intangible impacts include trust, understanding each other's perspectives, and ideas and management practices that are being used beyond the project (Porensky interview). Their best practices are deep reflection, experimentation and learning together (Wilmer et al., 2018; Fernández-Giménez et al., 2019b).

CARM was designed to test key hypotheses arising from an academic debate in the rangeland science and management community (Briske et al., 2011). The team was also responding to changing public demands for multiple ecosystem services on rangelands, and to a key gap in rangeland science: manager decision-making had been excluded from most grazing research in the USA for 8 decades. Several methodological and theoretical perspectives influenced project design. These were: (1) a tradition of customer-oriented, applied, and 
TABLE 1 | Selected characteristics of six rangeland partnering case studies in North America, Europe, Africa, \& Asia.

\begin{tabular}{|c|c|c|c|c|c|c|}
\hline Characteristic & $\begin{array}{l}\text { CARM project, } \\
\text { Colorado, USA }\end{array}$ & Samburu, Kenyab & $\begin{array}{l}\text { Reto project, } \\
\text { Maasailand, East } \\
\text { Africac }^{c}\end{array}$ & $\begin{array}{l}\text { MOR2 project, } \\
\text { Mongoliad }^{d}\end{array}$ & Spain ${ }^{e}$ & $\begin{array}{l}\text { Pamir Mtns, } \\
\text { Afghanistan/Tajikistan }^{f}\end{array}$ \\
\hline Location of work & $\begin{array}{l}\text { Experimental station, } \\
\text { Colorado, USA }\end{array}$ & $\begin{array}{l}3 \text { communities, } \\
\text { Samburu, Kenya }\end{array}$ & $\begin{array}{l}5 \text { ecosystems, } 100 \\
\text { Maasai comm., Kenya } \\
(\mathrm{KN}) \text { \& Tanzania (TZ) }\end{array}$ & $\begin{array}{l}36 \text { counties, } 11 \\
\text { provinces, Mongolia }\end{array}$ & $\begin{array}{l}4 \text { sub-national } \\
\text { regions, Spain }\end{array}$ & $\begin{array}{l}8 \text { villages, Pamir Mtns, } \\
\text { Afghanistan \& Tajikistan }\end{array}$ \\
\hline Project Scale (years) & $\begin{array}{l}\text { Ranch level, } 10 \times \\
10 \mathrm{~km} \text { (10 years) }\end{array}$ & $\begin{array}{l}\text { County level, } 150 \times \\
225 \mathrm{~km}(6)\end{array}$ & $\begin{array}{l}\text { Int'l region, } 400 \times \\
650 \mathrm{~km}(15)\end{array}$ & $\begin{array}{l}\text { National, } 800 \times \\
1,200 \mathrm{~km}(8)\end{array}$ & $\begin{array}{l}\text { Regional, } 400 \times \\
400 \mathrm{~km} \mathrm{(3)}\end{array}$ & $\begin{array}{l}\text { Int'l region, } 250 \times \\
250 \mathrm{~km}(13)\end{array}$ \\
\hline Goals & $\begin{array}{l}\text { - Stakeholders } \\
\text { co-develop goals } \\
\text { and objectives } \\
\text { - Manage land to } \\
\text { pass it on to future } \\
\text { generations } \\
\text { - Collaboratively learn } \\
\text { and adapt } \\
\text { management based } \\
\text { on monitoring data, } \\
\text { stakeholder } \\
\text { knowledge, } \\
\text { and dialog }\end{array}$ & $\begin{array}{l}\text { - Share pastoral } \\
\text { knowledge \& } \\
\text { practice with } \\
\text { NGOs \& } \\
\text { conservancies } \\
\text { - Create co-learning } \\
\text { opportunities } \\
\text { - Drought planning } \\
\text { sheep \& } \\
\text { goat husbandry }\end{array}$ & $\begin{array}{l}\text { - Focus research on } \\
\text { issues identified by } \\
\text { community (breeds, } \\
\text { vaccine, tourism } \\
\text { profits, land use) } \\
\text { - Assess synergies \& } \\
\text { trade-offs between } \\
\text { pastoralism and } \\
\text { conservation } \\
\text { - Implement new } \\
\text { science models to } \\
\text { support communities } \\
\text { \& influence policy }\end{array}$ & $\begin{array}{l}\text { - Co-design research } \\
\text { to address priority } \\
\text { pastoral issues } \\
\text { - Assess CBRM social } \\
\text { \& ecological } \\
\text { outcomes, and } \\
\text { whether CBRM } \\
\text { increases system } \\
\text { resilience to climate } \\
\text { and socio-economic } \\
\text { changes } \\
\text { - Build capacity of } \\
\text { Mong. researchers to } \\
\text { do TD science }\end{array}$ & $\begin{array}{l}\text { - Co-create } \\
\text { knowledge with } \\
\text { women pastoralists } \\
\text { - Document women's } \\
\text { lived experiences as } \\
\text { livestock keepers } \\
\text { - Increase visibility of } \\
\text { women pastoralists } \\
\text { - Support pastoral } \\
\text { women's networks } \\
\text { to advance their } \\
\text { agendas for social, } \\
\text { economic and } \\
\text { political change in } \\
\text { the } \\
\text { rural/livestock sectors }\end{array}$ & $\begin{array}{l}\text { - Build trust } \\
\text { - Co-generate } \\
\text { knowledge } \\
\text { - Create an outcome } \\
\text { that is useful to } \\
\text { communities to } \\
\text { secure their } \\
\text { livelihoods \& } \\
\text { food systems } \\
\text { s }\end{array}$ \\
\hline $\begin{array}{l}\text { Human development } \\
\text { index }\end{array}$ & Very high, 0.92 & Med, 0.57 & $\begin{array}{l}\text { - Kenya = Med, } 0.57 \\
\text { - Tanzania = } \\
\text { Low, } 0.53\end{array}$ & High, 0.74 & Very high, 0.89 & $\begin{array}{l}\text { Tajikistan = Med, } 0.66 \text {, } \\
\text { Afghanistan = Low, } \\
0.50\end{array}$ \\
\hline $\begin{array}{l}\text { Biome, rainfall mean } \\
\text { or range }\end{array}$ & $\begin{array}{l}\text { Temperate steppe, } \\
\text { mean }=341 \mathrm{~mm}\end{array}$ & $\begin{array}{l}\text { Tropical savanna, } \\
400-600 \mathrm{~mm}\end{array}$ & $\begin{array}{l}\text { Tropical savanna, } \\
\text { 400-600 mm }\end{array}$ & $\begin{array}{l}\text { Temperate steppe } \\
\text { 130-400 mm }\end{array}$ & $\begin{array}{l}\text { Medit. grasslands, } \\
\text { woodlands \& } \\
\text { mountains, } \\
250-1,800 \mathrm{~mm}\end{array}$ & Temperate mountains \\
\hline Dominant land tenure & $\begin{array}{l}\text { Public \& private land. } \\
\text { Grazing on public land } \\
\text { depends on owning } \\
\text { private land }\end{array}$ & $\begin{array}{l}\text { Public, private and } \\
\text { community land }\end{array}$ & $\begin{array}{l}\text { KN = Private, group } \\
\text { ranch \& public land. TZ } \\
=\text { Village \& public } \\
\text { (trust) land }\end{array}$ & $\begin{array}{l}\text { Public land used in } \\
\text { common by } \\
\text { pastoralists }\end{array}$ & $\begin{array}{l}\text { Private, public, local } \\
\text { commons }\end{array}$ & $\begin{array}{l}\text { Public and private } \\
\text { ownership }\end{array}$ \\
\hline Stakeholder types & $\begin{array}{l}\text { Govt, NGOs, } \\
\text { ranchers, ID } \\
\text { researchers }\end{array}$ & $\begin{array}{l}\text { PhD student, } \\
\text { pastoralists, comms }\end{array}$ & $\begin{array}{l}\text { Govt, NGOs, } \\
\text { pastoralists, ID } \\
\text { researchers, comms }\end{array}$ & $\begin{array}{l}\text { Govt, NGOs, } \\
\text { pastoralists, ID } \\
\text { researchers }\end{array}$ & $\begin{array}{l}\text { NGOs, network, } \\
\text { pastoralists, } 3 \text { ID } \\
\text { researcher-activists }\end{array}$ & $\begin{array}{l}\text { NGOs, pastoralists, ID } \\
\text { researchers }\end{array}$ \\
\hline $\begin{array}{l}\text { Team size (\# of } \\
\text { disciplines) }\end{array}$ & Large (5) & Small (1) & Large (6) & Large (5) & Small (3) & Moderate (3) \\
\hline $\begin{array}{l}\text { Partnership process } \\
\text { outputs }\end{array}$ & $\begin{array}{l}\text { Collab relations, knowl } \\
\text { int, co-prod, soc learn, } \\
\text { network, implement } \\
\text { action }\end{array}$ & $\begin{array}{l}\text { Collab relations, } \\
\text { knowl int, co-prod, } \\
\text { soc learn, capacity }\end{array}$ & $\begin{array}{l}\text { Collab relations, knowl } \\
\text { int, co-prod, soc learn, } \\
\text { capacity, implement } \\
\text { action }\end{array}$ & $\begin{array}{l}\text { Collab relations, knowl } \\
\text { int, co-prod, soc learn, } \\
\text { capacity, network }\end{array}$ & $\begin{array}{l}\text { Collab relations, knowl } \\
\text { int, co-prod, soc learn, } \\
\text { network }\end{array}$ & $\begin{array}{l}\text { Collab relations, knowl } \\
\text { int, co-prod, soc learn, } \\
\text { capacity, network }\end{array}$ \\
\hline $\begin{array}{l}\text { Partnership product } \\
\text { outputs }\end{array}$ & $\begin{array}{l}\text { Meetings, } \\
\text { experiments, co-prod } \\
\text { research, pubs, } \\
\text { reflective evals }\end{array}$ & $\begin{array}{l}\text { Meetings, co-prod } \\
\text { research, feedback } \\
\text { workshops, thesis }\end{array}$ & $\begin{array}{l}\text { Meetings, co-prod } \\
\text { research, outcome } \\
\text { maps, pubs, tech } \\
\text { transfer, new NGO }\end{array}$ & $\begin{array}{l}\text { Meetings, co-prod } \\
\text { research, reflective } \\
\text { evals, pubs, feedback } \\
\text { workshops, trainings }\end{array}$ & $\begin{array}{l}\text { Meetings, } \\
\text { co-interpreted } \\
\text { research, feedback } \\
\text { workshops, reports, } \\
\text { pubs }\end{array}$ & $\begin{array}{l}\text { Curriculum, } \\
\text { co-interpreted research, } \\
\text { conference, K-S } \\
\text { platform, ML pubs }\end{array}$ \\
\hline Outcomes \& impacts & $\begin{array}{l}\text { Social, biodiversity } \\
\text { conservation, food } \\
\text { production, drought } \\
\text { resilience }\end{array}$ & $\begin{array}{l}\text { Stronger leader, } \\
\text { reframed gender, } \\
\text { empowered voices }\end{array}$ & $\begin{array}{l}\text { Social, econ, ecol, } \\
\text { animal health, reframed } \\
\text { narrative, leaders, } \\
\text { policy }\end{array}$ & $\begin{array}{l}\text { Social, team science } \\
\text { process, leaders }\end{array}$ & $\begin{array}{l}\text { Empowered voices, } \\
\text { reframed gender, } \\
\text { networks }\end{array}$ & $\begin{array}{l}\text { Empowered voices, } \\
\text { reframed narrative, } \\
\text { education, policy, } \\
\text { leaders }\end{array}$ \\
\hline Best practices & $\begin{array}{l}\text { Interaction intensity \& } \\
\text { experimentation }\end{array}$ & $\begin{array}{l}\text { Multiple visits to } \\
\text { design study }\end{array}$ & $\begin{array}{l}\text { Community \& policy } \\
\text { facilitators }\end{array}$ & $\begin{array}{l}\text { Team science, } \\
\text { reflection, evaluation }\end{array}$ & $\begin{array}{l}\text { Co-creation, linkage to } \\
\text { activism }\end{array}$ & $\begin{array}{l}\text { TD process, impact on } \\
\text { policy }\end{array}$ \\
\hline
\end{tabular}

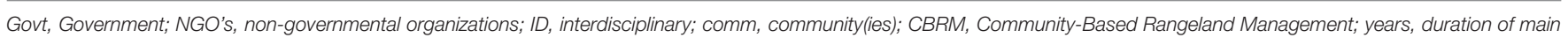

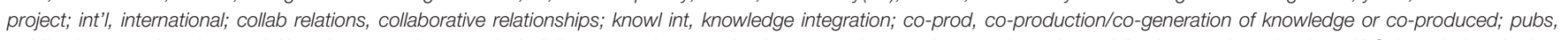

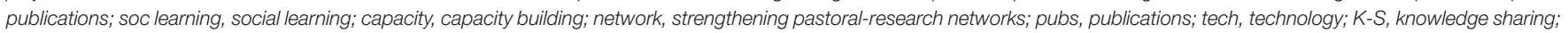

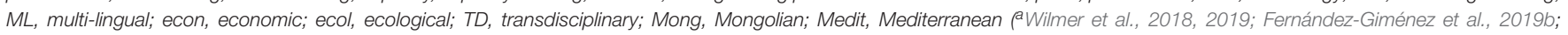

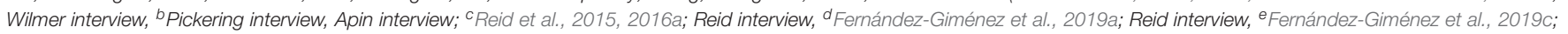
Fernández-Giménez interview; ' Kassam, 2010; Robinson et al., 2010; Kassam et al., 2011, 2018; g UNDP, 2019). 
cooperative agricultural research within the lead government agency (USDA-ARS); (2) participatory agricultural research (Uphoff, 1986); and (3) the collaborative adaptive management literature (Susskind et al., 2012; Beratan, 2014). These traditions inspired: (a) inclusion of ranchers, conservation organizations, and government agencies throughout all stages of the ranchscale, long-term research project, (b) the scale and structure of the project's experimental design, (c) the collaborative and adaptive format of decision-making in CARM; and (d) multi- and trans-disciplinary approaches to research, involving academic, professional and local knowledge of rangeland ecosystems, wildlife, economics, social science, and livestock.

\section{Drought Project, Samburu, Kenya (Pickering, Yasin Interviews)}

The Samburu project lasted 6 years from 2014 to 2019 and is a single investigator, multi-county project designed to share pastoral knowledge with powerful NGOs, create colearning opportunities and contribute to drought planning concerning sheep and goat husbandry. The partnership team was made up of the lead inter-disciplinary researcher (social and ecological scientist) plus 2 main pastoral coresearchers and 10 field assistants. The lead researcher started out focusing on conservation issues, but through longterm consultation with communities, shifted to a focus on women, sheep and goats and drought. The team used the processes of co-production of knowledge, social learning, capacity building, empowerment of voices and reframing the narrative. They think their intangible impacts are inclusion of diverse voices (young warriors, women), creating unique conversations within the community about drought, and building the capacity of Samburu leaders. Their best practices were long-term identification of the research problem through wide consultancy with community members, government and non-profits.

This case study used a collaborative-ethnographic approach (Shirk et al., 2012; Fiske et al., 2014). The team also came into the work with personal ethical stances about the need to listen and collaborate with the community so research would benefit diverse and underrepresented stakeholders in community-based rangeland management (Shirk et al., 2012). In this case, this ethical approach led to three initial field visits to Kenya to consult with NGOs and community members, while making sure to try to include marginalized voices, all to help identify the challenges, most appropriate research questions and methods, and co-interpret some of the results. This was followed by another 2.5 months testing data collection methods and continuing conversations with community members before any data was collected. The full ethnographic research-approach with community focus group discussion methods did not come until toward the end of 9 months of fieldwork (Fiske et al., 2014; Nyumba et al., 2018). Thus the entire research period was a process of checking and re-checking with community members and other stakeholders, with the ethnographic methods added at the end of the research.

\section{Reto Project, Maasailand, Kenya and Tanzania (East Africa, Reid Interview)}

The Reto-o-Reto ("you help us, we help you") project started in 1999, was very active for the next 11 years, and continues today. It is an international project, covering the traditional territory of the Maasai people in southern Kenya and northern Tanzania. Its goals were to focus on research identified by community members and policy makers and implement new models of science to support and empower communities (Reid, 2012; Reid et al., 2014b, 2015, 2016a). The partnership team consisted of pastoralists, government managers, conservation NGO practitioners, interdisciplinary researchers in 6 ecosystems and about 100 communities. The problem of focus originated with the community through intensive consultation by the project's "community facilitators" with regular updates and adaptation by the partnership team throughout the project. The partnership had a rapid adaptive learning cycle and measured outcomes with an outcome mapping technique (Earl et al., 2001). They used processes like co-production of knowledge, social learning, capacity building, and empowerment of marginal pastoral voices to reframe narratives about pastoralism. Their intangible impacts included development of confident leaders, building of new institutions and long-term impact on policy through participation on constitution review task forces. Their top best practice was the creation and funding of the team of six Maasai community and policy facilitators, who drove the project to be fully relevant to local pastoral communities and policy makers.

This case study was co-led by a geographer, economist and ecologist, who drew from existing theory when this case began in the late 1990s. At that time, one prominent theoretical framework was power dynamics as expressed in political ecology (Bryant, 1992; Rocheleau, 1995; Akama et al., 1996; Campbell et al., 2005), as well as the growing work in science and technology studies, specifically boundary organizations and transdisciplinary science (Guston, 2001; Klein, 2001; Cash et al., 2003; Goldman, 2006; Wyborn et al., 2019). The work was also informed, like the Kenya case, by the ethical stance of the researchers (Reid et al., 2014b, 2016a). The researchers shared goals to fully include pastoralists as part of the research, to integrate indigenous and scientific knowledge, and to fully connect research and action throughout the work. This work was not explicitly informed by participatory research frameworks or collaborative adaptive management, partly because these areas were less prominent in interdisciplinary science as the work began.

\section{MOR2 Project, Mongolia}

The MOR2 (Mongolian Rangelands and Resilience, also "mor" means "horse" in Mongolian) project started in 2008 as a large, 8year, national-scale project. Its goals were to understand climate and management impacts on rangelands and herder livelihoods, to assess the effects of community-based rangeland management (CBRM) institutions on social and ecological outcomes, and to understand the role of CBRM in system resilience to climatic and socio-economic changes (Fernández-Giménez et al., 2012, 2015, 2017; Ulambayar et al., 2017; Jamsranjav et al., 2018, 2019; Ulambayar and Fernández-Giménez, 2019). 
The partnership team consisted of pastoralists, government managers, conservation and livelihood NGO practitioners, and interdisciplinary researchers and worked across 36 counties in 10 provinces of Mongolia. The focal issues originated from a national workshop before the major grant for the project was written, allowing pastoral and governmental priorities to strongly shape the goals of the project. The partnership particularly excelled at inclusion of both Mongolian and American scientists, and the deep reflections about the team science conducted by this project (Fernández-Giménez et al., 2019a). They emphasized processes like intensive social learning and reflection, comprehensive capacity building, integration of knowledges and reframing of narratives about pastoralism. Their intangible impacts were long-term impacts on the scientific team, leadership development and influences on policy. Their best practices included the team science and reflection, yearly meetings with practitioners and government decision-makers at the national level, regional workshops with local and regional decision-makers at the end of the project and evaluation of MOR2 learning opportunities.

The broad MOR2 project was conceptualized using the socialecological systems framework (Ostrom, 2009), resilience theory (Gunderson and Holling, 2002), the theory of common pool resource governance (Ostrom, 1990; Agrawal, 2002), and nonequilibrium rangeland dynamics theory (Ellis and Swift, 1988). The team science aspect of MOR2 was guided by the science of team science literature and communications theory applied to interdisciplinary research teams (Thompson, 2009). The field research applied a range of different discipline-specific methods including social science interviews and questionnaires, plotbased ecological field sampling, remote sensing, and hydrological measurements which were integrated in a complex databased and through a variety of quantitative and qualitative analysis strategies. Most salient to this chapter/article were the repeated interviews and open-ended surveys of research team members, and facilitated reflective discussions by the team (FernándezGiménez et al., 2019a).

\section{Co-Creation Project, Spain}

This project started in 2018 as a small, 2-year, sub-nationalscale project to understand women's pathways into extensive livestock keeping, women's roles as tradition-keepers and change agents in Spanish pastoral systems, and to co-create knowledge for action with women pastoralists. The partnership team consisted of pastoralists, a pastoral network, scholar-activists and interdisciplinary researchers working in 4 regions of Spain including Andalucia, Northwest Spain, the Central Pyrenees and Aragón, and Catalunya. The problem emerged out of researcher exploration, experience and awareness of the lack of scientific research on women around pastoralism in Spain, and was refined throughout the project though collaboration with the statewide network of women pastoralists "Ganaderas en Red" and workshops with them and women pastoralists. This project is unique in that it had an explicit activism goal to support women pastoralists own pathways in their empowerment and social visibility and had strong networking. The team used processes including co-creation of knowledge, networking and empowerment of voices to reframe the scarce and frequently partial narratives about women in pastoralism with social learning as a major outcome. The team hopes their future intangible impacts will be a strong reframing of gender roles and value in Spanish pastoralism, and better social and policy support for women pastoralists. Their best practices included co-creation of knowledge, mutual care and support and their strong linkage to activism (Fernández-Giménez and Estaque, 2012; Fernández-Giménez et al., 2019c).

The Spanish case took a qualitative, constructivist research approach (Moon and Blackman, 2016) but did not adopt a specific theoretical framework at the beginning. Instead, as we worked with the data, we drew on theories of gender in agriculture and natural resources from rural sociology and geography, [e.g., (Whatmore, 1991; Sachs, 1996; O’Shaughnessy and Krogman, 2011; Sachs et al., 2016)], and on feminist political ecology [e.g., (Harcourt and Nelson, 2015)], as they resonated with our data and co-produced findings. We applied a feminist methodology from the outset, aspiring to the following tenets of feminist research. (1) An epistemology that takes knowledge as partial and situated (Haraway, 1988, 1991). (2) Transparency and ongoing reflexivity regarding researchers' positionalities, that is, how our life experiences, social identities, beliefs and values shape our relationships to the research topic, methods and participants (England, 1994). (3) Awareness of power dynamics, an aim to do research with not on participants, and to demonstrate reciprocity with study participants and communities (Cook and Fonow, 1985; Huisman, 2008). (4) An emancipatory goal that research support participants in advancing their agendas for social change. We realized these principles to varying degrees, by engaging with women pastoralists and/or organizations representing them in research design, data collection, analysis and interpretation, and by reflecting on and interrogating our process within the research team. The most important elements of this were repeated interactions with research participants over time via in-person and virtual workshops, individual correspondence via email and Whatsapp, and continual discussions among the research team throughout the analysis and writing process.

\section{Ecological Calendar Project, Pamir Mountains, Afghanistan and Tajikistan}

This project started in 2006 and now is a moderately large, 13year, international-scale project in 5 villages in the international Pamir Mountains to build trust, co-generate knowledge and create an outcome that is useful to communities to secure their livelihoods and food systems (Kassam, 2009b, 2010; Kassam et al., 2011, 2018). At the core of the project is work on understanding and using ecological calendars of the human body (Kassam et al., 2011). The partnership team consisted of pastoralists and interdisciplinary researchers, and sometimes purposely excluded top-down government involvement. The problem emerged out of researcher exploration and was refined throughout the project through interviews with agro-pastoralists. This project had a strong focus on integration of agro-pastoralist and researcher knowledge and practical use of traditional ecological calendars. The team emphasized processes including co-generation of knowledge, social learning, capacity building, and empowerment 
of voices to reframe the narrative about agro-pastoralism. Their intangible impacts were development of strong leaders and impact on national climate change policy. Their best practices included the transdisciplinary process (see Figure 1 below) and their impact on policy.

The primary objective of the Ecological Calendars Project is to develop context-specific adaptive and anticipatory capacity to anthropogenic climate change at the level of villages and towns. Therefore, the objective informed the methodology. The research process in the Pamirs partnership was guided by three theoretical frameworks. The first was participatory action research, which lays out the process for interaction between communities of inquiry (researchers) and communities of social practice (farmers, herders, fishers). This process is the co-generation of insight described in this paper from setting the research agenda, undertaking the research through to implementation of policy action (Greenwood and Levin, 2007). The second framework was transdisciplinarity, which situates the co-generation of knowledge outside the ivory tower of academia (Kassam et al., 2018). The final framework is the recognition of the complex connectivity between biological and cultural diversity which facilitates the co-generation of knowledge and transdisciplinarity based on the foundation of the ecological habitat (Maffi, 2001; Harmon, 2002; Kassam, 2009a).

\section{Case Summary and Comparisons Overall Biophysical and Social-Economic Characteristics}

Our cases span tropical (Kenya, Tanzania), Mediterranean (Spain), and temperate zones, from mountains (Pamirs, Spain) to savanna and woodlands (East Africa, Spain) to steppe (US, Mongolia) and semi-desert (Mongolia, Spain; Table 1). The Spanish cases cross a huge range of precipitation, encompassing the rainfall ranges of most other cases. The cases are part of countries that have Human Development Indices that vary from low (Tanzania, Afghanistan) to medium (Kenya, Tajikistan) to high (Mongolia) to very high (Spain, US). Most of the sites are home to transhumant pastoralists, who move among 2-4 seasonal pastures. Even the US ranching system can be considered transhumant (Huntsinger et al., 2010) although ranchers don't often move their households seasonally as often seen elsewhere. There is more private land ownership in the US and Spanish cases than elsewhere, but even US ranchers, if they graze federal land, do not control all the land where they graze their herds (Huntsinger et al., 2010). From case to case, ethnic diversity varies from low (US, Mongolia), to moderate (Kenya, Tanzania, Mongolia, Spain) to high (Tajikistan, Afghanistan).

\section{Driving Forces, Composition, Size, Leadership Goals}

All of these partnerships sought to address emergent complex problems through transformation, and all had elements of "strange bedfellow" or "unlikely" alliances (Hillis et al., 2020). All the cases created informal or formal partnerships with membership including pastoralists/pastoral communities and disciplinary/inter-disciplinary researchers (Table 1). The larger partnerships expanded their engagement to include government managers and NGOs (Colorado, East Africa, Mongolia, Pamirs).
Projects differed significantly in their size, with the Mongolia project stretching across a full nation and involving 5 disciplines, lasting 8 years. In contrast, another partnership by the same lead researcher was in Spain, worked in 4 sub-national regions with 3 disciplines. All cases were led by either disciplinary or interdisciplinary researchers and emphasized co-production/cogeneration and social learning as a key and transformative process in their work. Important to all partnerships was a focus on the process of partnership engagement and co-generation of knowledge, which was even more important than partnership outcomes and impacts. Partnership goals consisted of a diverse set of research goals, like drought, gender, animal production, and some had explicit partnership goals, like co-creation of knowledge (several), developing community-driven research problems (East Africa), and creation of useful outcomes (Pamirs).

\section{Partnership Outputs: Processes and Products}

Our cases created both processes and products as outputs (Table 1). Process outputs included creating collaborative research and action teams; integrating diverse experiential, Indigenous, local, practical, technical and research knowledges; co-production/co-generation/co-creation of new knowledge together; social learning to understand issues and recommend action; building capacity of all team members, but especially pastoral community members; building strong research and action networks; and implementing management practices and promoting new governance structures and policies. Product outputs consisted of an array of communication products (theses, publications, reports, oral presentations, websites, evaluations), education materials (training manuals, training courses, university curricula), learning and networking opportunities (peer-to-peer pastoral visits, field visits, conferences, research and community feedback workshops, policy meetings, retreats), social events (national holidays, award celebrations, meals together), and technology transfer (a vaccine and a better bull) and a new non-profit organization.

\section{Outcomes, Long-Term Impacts}

We will discuss these aspects of our cases in the section on outcomes and impacts that follows the definitions section below.

\section{KEY DEFINITIONS, CRITICAL CONCEPTS AND PROCESSES}

\section{Key Definitions}

\section{Science With Society and SWS Partnerships}

The approach taken by the partnerships here has many abstract and unclear names in the literature and in practice, as described above. We prefer to use a name for this approach that it is clearly understandable, strongly implies linked research and action, and is powerful. Thus, we avoid calling this approach "transdisciplinary research" since it is an abstract term and unclear. We use the word "science," rather than "research," because of the implication of power in the word "science." We then define "science" broadly to include several areas of inquiry including western science, Indigenous science and humanities research. Then, we prefer the phrase "science with 


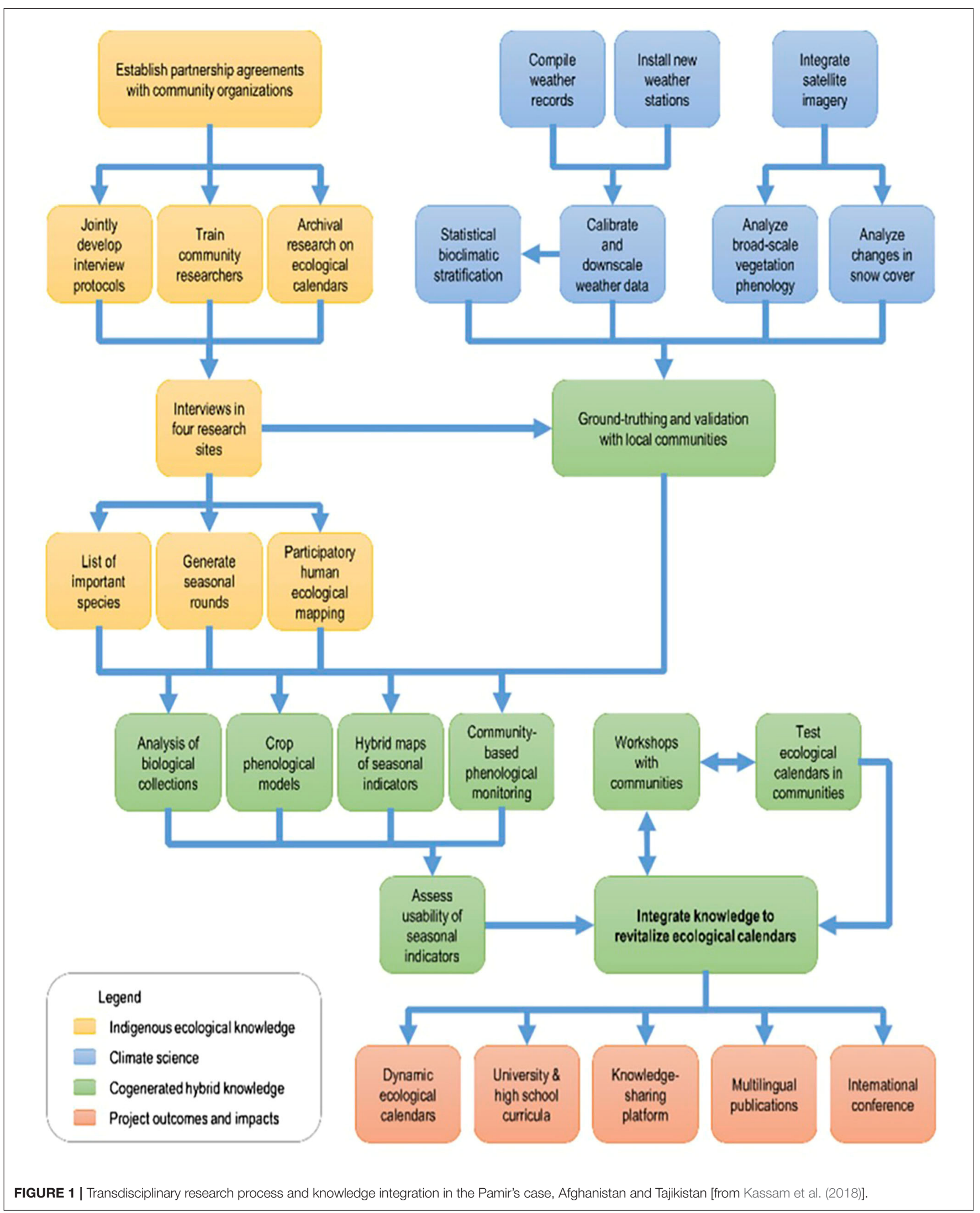




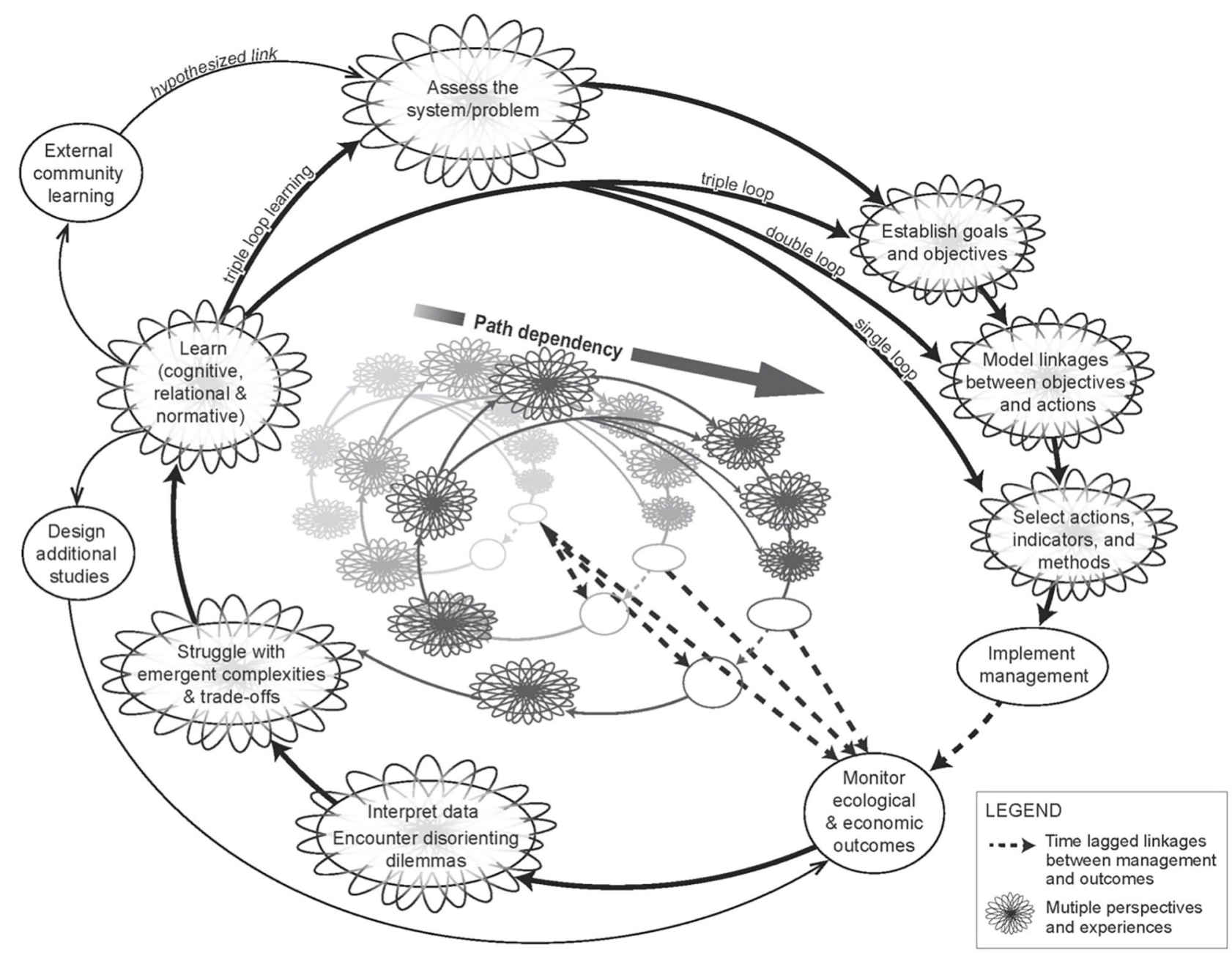

FIGURE 2 | Collaborative adaptive management cycle undertaken by the Colorado (CARM) case, showing single to triple loop learning, as well as disorienting dilemmas, emergent complexities, trade-offs and path dependency, figure from Fernández-Giménez et al. (2019b).

society" [after (Seidl et al., 2013)] rather than "science for society" to strongly imply the co-creation process with use of the word, 'with'. Then this paper is about "science with society (SWS) partnerships." The "community of inquirers" (Kassam et al., 2018) are then both scientists and researchers. Then the "communities of practice" are "practitioners" and "actors" which include pastoralists, ranchers, conservation practitioners, government managers, business people, and regular citizens. Of course, as described here, there are hybrid categories in these communities, including "pastoralist-scholars," "scholar-ranchers," "pracademics," "practitioner-scholars," "scholar-practitioners," and "scholar-activists," just as there are, within science, interdisciplinary "social-ecological" scientists.

\section{How Interdisciplinary and Transdisciplinary Research Relates to Science With Society}

Like (Klein, 1990), we define interdisciplinary research as the use of more than one scholarly discipline to address a research issue, including attempts to integrate different disciplines into new forms. Transdisciplinary research, often also interdisciplinary, is defined as science that brings together research with society, "transforming" the research problem (Pohl and Hirsch Hadorn, 2008) and its potential solutions. In this paper, we substitute the term, "science with society," for the terms, "interdisciplinary research" and "transdisciplinary research," because the former is clearer and more powerful. Science with society (or SWS) initiates a transformation process that includes: "societal agenda setting, collective problem framing, a plurality of perspectives, integrative research processes, new norms for handling dissent and controversy, in-depth treatment of uncertainty and of diversity of values, extended peer review, broader and more transparent metrics for evaluation, effective dialog processes, and stakeholder participation" (Cornell et al., 2013):60. This approach "goes beyond the 'primacy of science' as well as the 'primacy of practice', establishing a third epistemic way" (Lang et al., 2012):26. Our cases all take an SWS 
approach since they all address linked social, economic and ecological issues of importance to society (interdisciplinary) and engaged with members of society throughout the SWS process (transdisciplinary).

\section{Key Processes in Science With Society}

Of these general processes of SWS globally, we will define and dive into the concepts of the seven processes that were important to our rangeland cases here, which appear as "partnership process outputs" in Tables 1, 2. The first process is building collaborative relationships with a goal to build trust, create more inclusion and respect, empower marginalized voices, create collective buyin for project outcomes, and create a convening platform for collaborative work together. Relationships are the core of this approach and are important to its short and long-term success. The emphasis on relationships is important because it shifts the foundation of this work from an underlying model of neoliberal Western culture to the more global, cross-cultural model of relationships and collectivism. For example, in our Mongolia case, the leader of the research team worked for years as a single researcher in the field, slowly building relationships with communities and government. She then created the MOR2 project, with a highly interdisciplinary team, and started the project by bringing together these researchers, community members and government officials in an intensive workshop to design the research so it answered key community and policy questions.

Here, our cases often fall under a broad definition of the second process, co-production (or co-generation), which is a process "that iteratively brings together diverse groups and their ways of knowing and acting to create new knowledge and practices to transform societal outcomes" (Wyborn et al., 2019):322. Co-production has at least four aspects: material (what is), normative (what should be), cognitive (what we think) and social (what we do) (Wyborn, 2015). Each of the cases here used some aspect of co-production in their research process.

A note of caution here: (Chambers et al., in review), looking across 32 co-production cases around the world, found that coproduction was the only outcome that delayed accomplishment of other outcomes. They think this is because co-production "overly fetishizes the role of delivering scientific knowledge to create change and legitimizes researchers' control of the process." This then slows down achievement of other outcomes. They recommend that collaborative work focus on shaping relations, practices, and institutions, with knowledge production playing an integrated role in those processes.'

Here, we take a broad view of the co-production process to put science and action on equal footing. Researchers can tend to put high value on "expanding the knowledge base," when the action outcomes are often more important to community members and practitioners (Lang et al., 2012). Practitioners can tend to put more emphasis on action and devalue research. To avoid these two pitfalls, we see co-production for what it is meant to be: a purposeful linking of knowledge and action together with strong feedbacks. Here, the CARM and East African cases used repetitive reflection and planning meetings, sometimes monthly, to align the incentives and goals of research and action.
Thus, co-production is the entire collaborative process, where collaborative practices lead to expanding the knowledge base and increased capacity which then leads to action (and outcomes and impact) affecting well-being, rangeland health, policy, services, products, funding and institutions (Wyborn et al., 2019). In this framework, co-production is nested within ever-larger spheres of context including communities and stakeholder groups, existing systems of policy and institutions, and social and cultural norms.

In practice, in our view, the next two processes in our cases, knowledge integration and social learning, are the heart of successful co-production of knowledge with action. The broadest or most general type of knowledge is Indigenous or traditional knowledge which includes empirical, practical, normative, purposive and spiritual knowledges, and practices and beliefs (Berkes, 2009; Pickering Sherman and Sherman, 2010). Western knowledge can be broken down into western scientific knowledge (e.g., physics economics, sociology, ecology), practical knowledge (e.g., engineering, medicine, rangeland management), normative knowledge (e.g., law, planning, politics) and purposive (e.g., ethics, values, philosophy) (Max-Neef, 2005; Reyers et al., 2010; Tengo et al., 2014).

Our cases all "bring together" different knowledges, principally diverse pastoralist knowledges and interdisciplinary researcher knowledges, and some also integrate knowledges from conservation practitioners, government managers, policy makers and/or activists. In the Pamir's case, Kassam and team provide rich detail (Kassam et al., 2018) of the independent knowledge domains they brought together (Indigenous and climate science) and what hybrid knowledge they co-generated together (crop models, ecological calendars of the human body). They also specify the practical, educational, networking, and scientific outputs from that integration (Figure 1).

Social learning is "a change in understanding that goes beyond the individual to become situated within wider social units or communities of practice through social interactions between actors within social networks" (Reed et al., 2010):6. Social learning is thought to occur in multiple loops, resulting in progressively deeper reflection and change in an individual or group as they learn (Keen et al., 2005; Fernández-Giménez et al., 2019b). Single loop learning is about cause and effect, double loop learning addresses our assumptions or mechanisms (how things work) and triple loop learning can revise our values, norms and actions (Fernández-Giménez et al., 2019b). These learning loops occur within science, within practice and between science and practice (Lang et al., 2012). Triple loop learning can be simplified into three stages: a disorienting dilemma, critical reflection and reflective discourse (Pennington et al., 2013). Here, we treat social learning as a process output, but it can also be considered an outcome.

Our Colorado case used the collaborative adaptive management cycle which we will use here to illustrate how to embed social learning with management experimentation and action (Figure 2) (Fernández-Giménez et al., 2019b). This cycle was tested by a team that experimented with contrasting grazing strategies to improve cattle weight gain and grassland bird diversity. They found that they had to adapt a simple adaptive learning cycle into one with more complexity, as depicted in 
TABLE 2 | Seven types of impact pathways as a result of process outputs partners implement that form a 'process' a theory of change for our rangeland partnerships.

\begin{tabular}{|c|c|c|c|c|}
\hline $\begin{array}{l}\text { Partnership process } \\
\text { output (from Table 1) }\end{array}$ & Outcomes (2-5 years) & $\begin{array}{l}\text { Desired } \\
\text { action/impacts (5-10 } \\
\text { years) }\end{array}$ & $\begin{array}{l}\text { Intangible long-term } \\
\text { impacts ( } 20+\text { years?) }\end{array}$ & $\begin{array}{l}\text { Which case achieved } \\
\text { what? }\end{array}$ \\
\hline $\begin{array}{l}\text { 1. Collaborative } \\
\text { relation -ships: Team } \\
\text { convenes diverse } \\
\text { collaborative group that } \\
\text { builds relationships }\end{array}$ & $\begin{array}{l}\text { Stronger trust \& } \\
\text { relationships, more } \\
\text { inclusion \& respect, } \\
\text { re-framed narrative, } \\
\text { empowered voices }\end{array}$ & $\begin{array}{l}\text { Continued collaboration } \\
\text { by diverse teams on } \\
\text { big issues; community } \\
\text { takes leadership role }\end{array}$ & $\begin{array}{l}\text { Confident leaders have } \\
\text { big impacts, team } \\
\text { members work together } \\
\text { on new projects, less } \\
\text { polarization, } \\
\text { decolonization }\end{array}$ & $\begin{array}{l}\text { Outcomes: All cases } \\
\text { Impacts: EA,M }\end{array}$ \\
\hline $\begin{array}{l}\text { 2. Knowledge } \\
\text { integration: Team } \\
\text { brings together local, } \\
\text { indigenous \& research } \\
\text { knowledges, reframes } \\
\text { story }\end{array}$ & $\begin{array}{l}\text { Govt, NGOs see value } \\
\text { in integrating \& using } \\
\text { diverse knowledges to } \\
\text { identify problems \& } \\
\text { needed action }\end{array}$ & $\begin{array}{l}\text { Govt, civil society use } \\
\text { integrated knowledge to } \\
\text { develop policy \& } \\
\text { practice that supports } \\
\text { pastoralism }\end{array}$ & $\begin{array}{l}\text { Pastoral livelihoods \& } \\
\text { rangelands are healthier } \\
\text { \& more resilient; } \\
\text { marginalized pastoral } \\
\text { voices respected \& } \\
\text { supported }\end{array}$ & $\begin{array}{l}\text { Outcomes: All cases } \\
\text { Impacts: EA,M,P }\end{array}$ \\
\hline $\begin{array}{l}\text { 3. Co-production: } \\
\text { Team creates } \\
\text { knowledge that is } \\
\text { relevant and useful for } \\
\text { community, NGOs, } \\
\text { govt }\end{array}$ & $\begin{array}{l}\text { Govt, NGOs consider } \\
\text { co-prod knowledge } \\
\text { when planning future } \\
\text { work }\end{array}$ & $\begin{array}{l}\text { Community uses } \\
\text { evidence on mgmt } \\
\text { practices, govt, NGOs } \\
\text { develop policy \& } \\
\text { practice that is more } \\
\text { evidence-based }\end{array}$ & $\begin{array}{l}\text { Research-action } \\
\text { networks change how } \\
\text { science gets done \& } \\
\text { policy developed, } \\
\text { networks support } \\
\text { activism for policy } \\
\text { change }\end{array}$ & $\begin{array}{l}\text { Outcomes: EA,M,P,C } \\
\text { Practice Imp: C } \\
\text { Policy Imp: EA,M,P }\end{array}$ \\
\hline $\begin{array}{l}\text { 4. Social learning: } \\
\text { Team learns together } \\
\text { and jointly problem } \\
\text { solves }\end{array}$ & $\begin{array}{l}\text { Team members } \\
\text { change their mental } \\
\text { models \& vision of the } \\
\text { possible \& influence } \\
\text { others }\end{array}$ & $\begin{array}{l}\text { Team members } \\
\text { implement learning } \\
\text { process \& new mental } \\
\text { models in policy \&/or } \\
\text { practice }\end{array}$ & $\begin{array}{l}\text { Mental models and } \\
\text { transformative learning } \\
\text { catalyzes systems, } \\
\text { values \& science to } \\
\text { transform }\end{array}$ & $\begin{array}{l}\text { Outcomes: All cases } \\
\text { Practice Imp: C } \\
\text { Policy Imp: EA,M,C }\end{array}$ \\
\hline $\begin{array}{l}\text { 5. Capacity: Team } \\
\text { builds capacity of all } \\
\text { members }\end{array}$ & $\begin{array}{l}\text { Pastoral members } \\
\text { become robust voice for } \\
\text { team \& stronger leaders; } \\
\text { researchers change } \\
\text { how they do science }\end{array}$ & $\begin{array}{l}\text { Stronger leaders } \\
\text { create more inclusive } \\
\text { policy \& practice } \\
\text { supporting pastoralism } \\
\text { \& healthy rangelands }\end{array}$ & $\begin{array}{l}\text { Inclusiveness \& justice } \\
\text { becomes the norm, } \\
\text { pastoralists sit at the } \\
\text { tables of power; science } \\
\text { becomes decolonized \& } \\
\text { democratized }\end{array}$ & $\begin{array}{l}\text { Outcomes: All cases } \\
\text { Impacts: EA,M }\end{array}$ \\
\hline $\begin{array}{l}\text { 6. Networks: Team } \\
\text { strengthen pastoral- } \\
\text { researcher-action } \\
\text { networks }\end{array}$ & $\begin{array}{l}\text { Network becomes } \\
\text { known and relied upon } \\
\text { \& expands to new } \\
\text { members }\end{array}$ & $\begin{array}{l}\text { Network influences } \\
\text { policy \& practice }\end{array}$ & $\begin{array}{l}\text { Networking becomes } \\
\text { the norm \& helps } \\
\text { transform systems, less } \\
\text { polarization }\end{array}$ & $\begin{array}{l}\text { Outcomes: Spain, M,C } \\
\text { Impacts: None }\end{array}$ \\
\hline $\begin{array}{l}\text { 7. Implement action: } \\
\text { Partnership implements } \\
\text { mgmt practices, } \\
\text { promotes new } \\
\text { governance }\end{array}$ & $\begin{array}{l}\text { Govt, NGOs use } \\
\text { partnership's best } \\
\text { practices /or } \\
\text { governance/climate } \\
\text { change } \\
\text { recommendations }\end{array}$ & $\begin{array}{l}\text { Ranchers implement } \\
\text { practices that better } \\
\text { support household } \\
\text { economies \& rangeland } \\
\text { health; governance } \\
\text { improves policy }\end{array}$ & $\begin{array}{l}\text { Action with research the } \\
\text { norm, new institutions } \\
\text { and policy improve } \\
\text { pastoral livelihoods \& } \\
\text { rangeland health }\end{array}$ & $\begin{array}{l}\text { Outcomes: C,EA,M } \\
\text { Mgmt Imp: C } \\
\text { Governance/climate: } \\
\text { EA,M,P }\end{array}$ \\
\hline
\end{tabular}

Cases: C, Colorado ${ }^{1} ;$ K, Kenya ${ }^{2}$; EA, East Africa ${ }^{3}$; M, Mongolia ${ }^{4}$; S, Spain ${ }^{5}$; P, Pamirs ${ }^{6}$; Imp, Impacts.

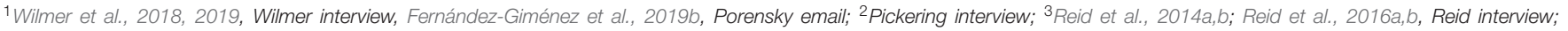

${ }^{4}$ Fernández-Giménez et al., 2019a; ${ }^{5}$ Fernández-Giménez et al., 2019c, Fernández-Giménez interview; ${ }^{6}$ Kassam et al., 2011, 2018, Kassam interview.

Figure 2. The team gained key insights from using this approach including encountering disorienting dilemmas which challenged their mental models with trade-offs and emergent complexities (Fernández-Giménez et al., 2019b). Disorienting dilemmas (Pennington et al., 2013) occur when participants encounter experiences and information that causes them to struggle and then replace their existing concepts with new ones, creating new mental models. Mental models are how we represent the world around us in our minds and form the basis of our decision making (Jones et al., 2011; Fernández-Giménez et al., 2019b).

Our last three processes are capacity building, networking and implementing action. The goal of the fifth process, capacity building, is to support participants in an SWS partnership to develop and refine the knowledge and skills to build and support strong SWS teams, to respectfully and thoughtfully engage with each other on those teams, and to negotiate how to work together and resolve conflict. This capacity applies to all members of the partnership from pastoralists to researchers, from the most senior to most junior member. We also found, particularly in our Mongolia and East Africa cases, that this capacity building was critical to long-term impacts on policy and practice. The sixth process, networking, means both informal social networking but also establishment and expansion of more formal networks. In the Spanish case, for example, the networking between the 
"ganaderas" (women pastoralists) and the researcher who worked in Mongolia and the US made the ganaderas feel they were part of a wider, international context. The last process is implementing action. This means engaging in action activities like changing a management practice, restoring land, and, in a more distant way, participating in policy and practice design workshops that lead directly to action implementation.

Finally, boundary spanning, which is not a process output in Table 1, is another key process in SWS that facilitates the co-production of knowledge by individuals, disciplines, sectors, organizations and across scales. This concept was originally applied to "boundary organizations" which are intermediaries that are accountable to both sides of organizational boundaries and convene, mediate, and negotiate among different stakeholders (Guston, 1999; Cash et al., 2003, 2006). The practical idea of a boundary organization is to reduce the cost of co-production and partnership building (Lemos et al., 2018). Boundary "partners" are those a program interacts with directly and hopes to influence (Earl et al., 2001). Boundary spanning individuals have a key function as apolitical intermediaries who serve as catalysts for a collaborative process (Barry et al., 2007; Hillis et al., 2020) and link disciplines, institutions, and scales (Reid et al., 2016b).

In our Spain and Kenya cases, both lead researchers were disciplinary boundary spanners as interdisciplinary scientists, mastering both ecological and social science disciplines and methodology. Another member of the team in the Spain case might be considered a boundary spanner as scientist and activist, as co-facilitator of the network of women pastoralists. In our other cases, most of the disciplinary scholars also took on boundary spanning roles by working with pastoralists, with other disciplinary scientists, and among different institutions. In the East Africa case, the entire research-and-pastoralist team was based out of a boundary spanning organization (the International Livestock Research Institute) and each member of the team had explicit boundary spanning roles with communities, policy and across scales (Reid et al., 2016b).

Boundary spanning roles for researchers become more complex and diverse as disciplinary research becomes interdisciplinary, then transdisciplinary and potentially transformative (Figure 3). As research goes from the inner to outer rings in Figure 3, it becomes more relevant to real world problems, more inclusive of different ways of knowing, and more political and value driven. Each successive ring, we would argue, transforms how science is done and how much it supports action by a wide range of actors and practitioners. It was only after reaching the third outer ring, for example, that our Pamirs, Reto and Mongolian cases started to have impacts on national policy in Afghanistan, Mongolia and Kenya. We will return to this figure in the last section of this paper.

\section{Outputs, Outcomes and Impact}

One of the biggest questions about these labor-intensive partnerships is this: Is all this effort worthwhile? Commonly, partnerships keep track of their outputs (knowledge, fora, and processes generated by partnership activities), their outcomes (changes in knowledge, skills, attitudes and relationships that cause changes in behavior of the partnership's clients or the environment) and their impacts longer term effects of the partnership's outcomes on society and the environment; modified from Earl et al. (2001), Belcher et al. (2019) (Table 1). Here, outputs include not only hand-tangible products, such as a map or a conference, but also processes, such as co-production or capacity building. We like this broad definition of outputs because processes often lead to important, long-lasting outcomes and impacts, even more than tangible products do, as we will see below in Table 2. Next are outcomes, which often occur in the first 5 years of the partnership. Impacts occur after outcomes and are more indirect, as a consequence, their cause attribution is difficult at best (Koontz and Thomas, 2006). Also, this chain of influence can create both positive and negative impacts and those can differ by different actors (Hillis et al., 2020). We will dig deeper into the outcomes and impacts of our cases in the next section.

\section{Transformations, Transformative Agency/Action and Transformative Learning}

Once achieved, when do outcomes and impacts become transformative? Here, we define a deliberate transformation as the creation of "a fundamentally new system when ecological, economic, or social structures make the existing system untenable" (Walker et al., 2004): 5. Partnerships deliberately work together to transform some aspect of a problem they tackle, and sometimes eventually cause their social-ecological system to cross "thresholds into new development trajectories" (Folke et al., 2010): 20. A transformation can be a tangible change, like a new policy, management practice or network, but also a more intangible change in ideas (Heikkila and Gerlak, 2019; Hillis et al., 2020), processes, learning (Pennington et al., 2013) and leadership that helps individuals and communities to build a better life (O'Brien, 2012). It can also be a change that allows researchers to do more creative, intellectually stimulating and impactful work (Pennington et al., 2013). We think that one of the most transformative aspects of partnerships is that they change the conditions that hold systems in place by changing paradigms to reconstruct power relations, build relationships and change mental models. All of our cases did this, exemplified by the CARM case, where researchers shared their expert power with ranchers and, together, the team built strong relationships and shifted their mental models of the world.

Transformative learning is a key part of transformation processes, often defined by triple loop learning (Mezirow, 1991). Social learning, a broader term, can lead to no change, incremental change (or an adaptation) or to a larger, transformative change. Transformative learning consists of an individual's ability to examine their own assumptions through critical reflection and open-mindedness, and the ability to listen to and take in perspectives and viewpoints different than their own (O'Brien, 2012). This also requires a respect for and desire to understand information from different knowledges. For example, this can include attempts to make science more inclusive of other knowledges by decolonizing the western European cultural assumptions underlying scientific methodologies (Smith, 2002). Transformative learning and willingness to experiment can play 


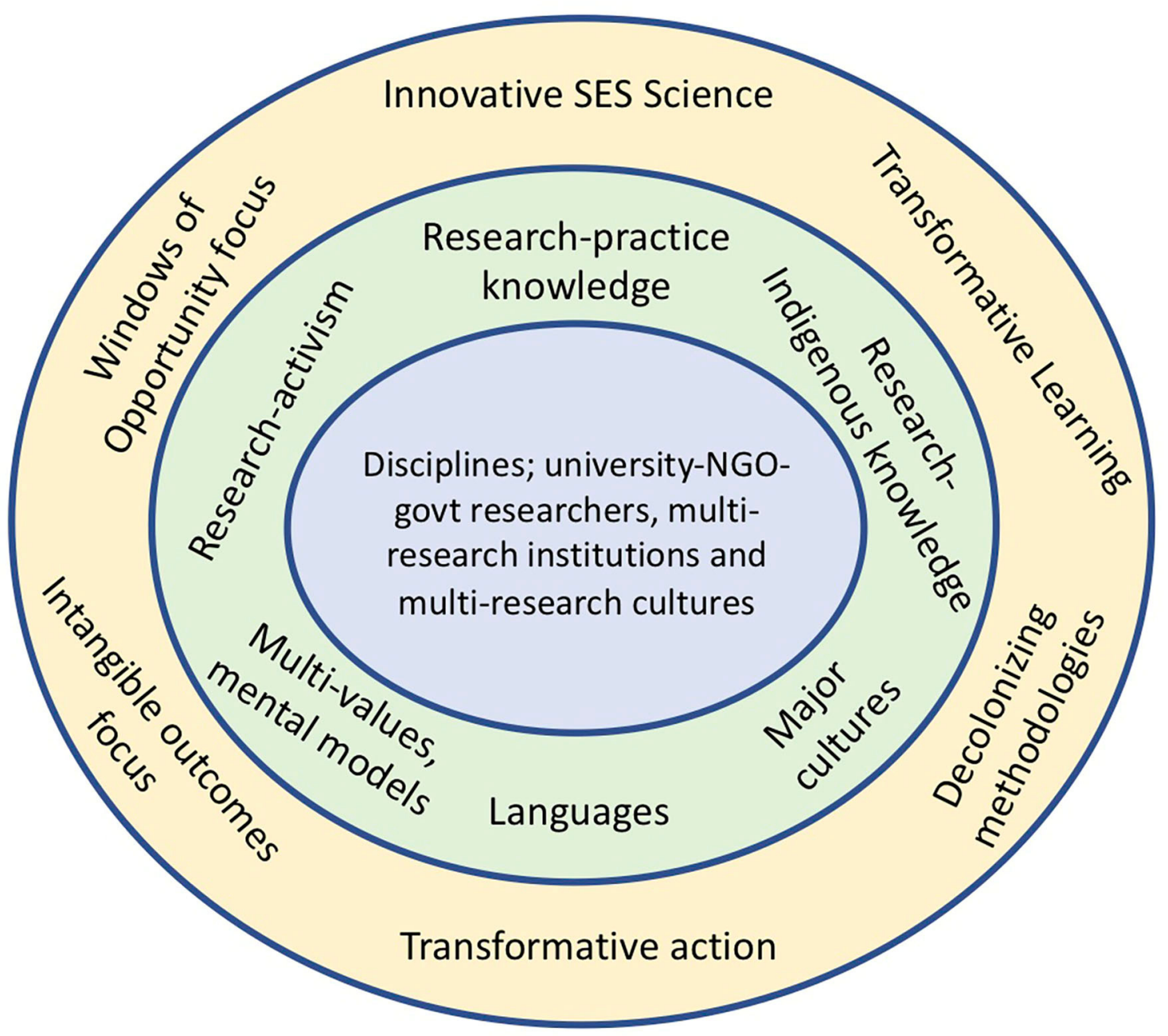

FIGURE 3 | The increasing complexity of boundary spanning when moving from interdisciplinary (blue center circle) to science with society (green middle ring). The outer orange ring is not boundary spanning, but rather the next evolution of the practices/strategies that could make science with society more transformative.

a role in systems transformation (Tschakert and Dietrich, 2010), like in our Colorado case.

\section{System Transformations}

How, when and why do systems transform? Gunderson and Holling (2002) describe the adaptive cycle of social-ecological systems, as a cycle from conservative, slow moving systems exhibiting incremental change to young, fast moving systems that exhibit rapid change, all connected in an adaptive cycle. Mature systems can rapidly transform if there is a trigger that creates a window of opportunity for transformation creating a specific moment in time to act (Olsson et al., 2006, 2017; Biggs et al., 2010). A window of opportunity opens when three things are in place: a group recognizes a problem, there is a solution at hand and there is the political will to implement it (Olsson et al., 2006). Thus, in that window, institutional entrepreneurs (Westley et al., 2013) in a collaborative partnership need to know what leverage points to use to catalyze fundamental and transformative change (Abson et al., 2017; Fischer and Riechers, 2019). Leverage points are "...places within a complex system (a corporation, an economy, a living body, a city, an ecosystem) where a small shift in one thing can produce big changes in everything" (Meadows, 1999):1. A leverage point that changes a policy constraint will have less impact than a leverage point that addresses a more fundamental change in mindsets, values or paradigms.

In rangelands systems, for example, a window of opportunity (outer ring, Figure 3) often forms when there is a crisis (trigger) that brings together diverse stakeholders (like ranchers and conservation organization professionals) around a big problem of common concern (Hillis et al., 2020), like a wildfire, water conflict, new extractive industry, or an impending regulation. Or it can occur when major new policy is implemented. Important for a system transformation is the role of a social innovation, which is "a new program, policy, procedure, product, process and/or design that seeks to address a social problem and to ultimately shift resource and authority flows, social routines and 
culture of the social system that created the problem in the first place (Westley et al., 2011)" (Westley et al., 2017):4. Institutional entrepreneurs can recognize a major window of opportunity and use this leverage point and the social innovation of a new policy to transform a pastoral system (see Table $\mathbf{1}$ for case examples).

\section{OUTCOME AND IMPACTS OF THESE SWS PARTNERSHIPS: WHAT ARE THEY AND ARE THEY TRANSFORMATIVE?}

\section{Theory of Change: Connecting Partnership Process Outputs to Outcomes to Impacts}

We developed a generalized "theory of change" based on our six cases, starting with the processes the SWS partnerships implemented and flowing through a sequence of outcomes, desired action/impacts to very long-term and less tangible impacts that we suspect will form decades after our work together (Table 2). A theory of change shows how the work contributes to a change process and the main actors involved, and can be used to track and evaluate partnership impacts over time (Belcher et al., 2019). Here, we focus on the positive aspects of these partnerships, with the recurring challenges of partnerships in the last section of this chapter. In addition, it is possible for any of the sequence of changes shown for the seven processes in Table 2 to be fully negative, however unlikely, leading to suppression of voices or more polarization, if participants are not ready to collaborate, or if the partnership is not carefully facilitated. More likely are partnerships that are too short term to solve problems because of the extra time and resources needed to make these partnerships successful (Hillis et al., 2020).

Our cases implemented most of seven important (and often sequential) processes, which we are calling process outputs ${ }^{2}$ (Tables 1, 2), which can also be thought of as social innovations, through process, sometimes aimed at particular leverage points. First, all cases engaged in a collaborative relationship-building process as an early step. Each partnership brought together participants with different values who had different social networks and held different political and religious beliefs. Some were from different nations, spoke different languages and were of different races. Thus, listening to each other, eating together, and becoming close colleagues (and often friends) was foundational to their partnership. It is also the most longlasting part of many partnerships. These relationships developed outcomes of trust, inclusion and respect, and importantly can empower voices of marginalized pastoralists to be heard by other participants. In the East Africa case, this empowerment was a main goal of the partnership (Reid et al., 2016b). All our longerterm cases (Colorado, Pamirs, Mongolia, East Africa) found that these outcomes can lead to continuing impacts as partners come together on other projects over time, building on the lessons of their initial work (Kassam \& Reid interviews).

All our cases also integrated existing knowledge, including some combination of Indigenous, traditional, experiential, local, practical, management and/or western scientific knowledges. In

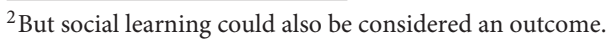

some cases, this integration "reframed the story (or narrative)" that pastoralism was considered primitive, backward and degrading to the land (Reid pers obs) or the role of women in pastoralism (Spain, Kenya). This sometimes led government, civil society and businesses (East Africa) to recognize this knowledge and to develop policy and practice supporting what they learned from pastoral-researcher knowledge (Table 2). In the Pamirs, the SWS partnership documented the importance of ecological calendars of the human body and brought this information to the attention of national policy makers, who then implemented new climate change policy based partly on this research of integrated agro-pastoral-research knowledge (Kassam interview \& report). In the East Africa case, the team highlighted pastoral knowledge that suggested that, contrary to the dominant story about pastoralism, livestock attract wildlife by creating short grassy areas where wildlife can see lions approaching. This "reframing" of the narrative by integrating knowledges provided a new narrative supporting the widespread establishment of pastoralled governance of wildlife in community conservancies [(Reid et al., 2016a), Reid interview]. This reframing was often voiced by community members when pastoral leaders led discussions in the East Africa case (Reid interview).

All of our cases also co-produced/co-generated new knowledge together. Our Kenya case started with intensive and repeated visits with Samburu pastoral communities, NGOs and government officials to determine how the research could be useful to their needs. The lead investigator, Pickering, entirely shifted his research focus, from community conservation to drought, in response to these consultations (Pickering interview). Our Spain case started with research issues identified by scholaractivists on the core team, but quickly engaged female pastoralists in interpreting interview and documentary information about their lives (Fernández-Giménez et al., 2019c). For all our cases, another key process was co-interpretation of the meaning of new knowledge during feedback workshops, reflection meetings, informal conversations and retreats. These enabled new knowledge to be more robust, more relevant, and locally owned by pastoralists and ranchers. In Mongolia, co-produced knowledge may have impacted policy development through the many meetings project members had with policy makers during the project and after it ended [(Fernández-Giménez et al., 2019a), Reid interview].

Social learning was more deliberate in some of our cases than others. Our Mongolia and Colorado cases deliberately added social learning to their project objectives and then took many opportunities to meet and reflect on their progress, their mental models, and their teamwork (Fernández-Giménez et al., 2019a,b). Our Colorado case used the collaborative adaptive management cycle which we will use here to illustrate how to embed social learning with management experimentation and action (Figure 2) (Fernández-Giménez et al., 2019b). This cycle was tested by a team that experimented with contrasting grazing strategies to improve cattle weight gain and grassland bird diversity. They found that they had to adapt a simple adaptive learning cycle into one with more complexity, as depicted in Figure 2. The team gained key insights from using this approach including encountering disorienting dilemmas which challenged 
their mental models with trade-offs and emergent complexities (Fernández-Giménez et al., 2019b). Even though our other cases did not highlight changing mental models as an outcome, the descriptions of their work indicate that this is a likely outcome for them as well.

In the Kenya case, social learning was important but not as deliberately evaluated. Co-author Yasin described their learning this way: "The best research gets diverse voices from the community, for instance in Samburu different age-sets and genders come together and learn from one another as the researcher shares information in these discussions. These discussions among diverse community members would not otherwise come together. They also will have many side discussions and continue to share information among themselves. Furthermore, these interactions build trust among different community members." (Yasin interview).

Perhaps the most far-reaching outcomes and impacts of our cases is when they formally or informally built capacity. This can be capacity of any participant, a pastoralist, a student, a scientist, a government manager or an NGO practitioner. Which participant was involved determines what realm the stronger capacity affects.

For example, students either leading (Kenya) or working on (Colorado, East Africa, Mongolia, Pamirs) our cases continue to have impacts on pastoral policy, management practices and how science is done. The Kenya case is led by a non-pastoral non-Kenyan. His impact will probably affect development/conservation practice in his future work and has already impacted how he thinks about and does science (Pickering interview). The East Africa, Mongolia and Pamirs cases all facilitated pastoralists from local communities (or pastoral nations like Mongolia) to complete their graduate degrees at universities in-country and around the world. In the East Africa and Mongolia cases, those students who finished their degrees more than 4-5 years ago are now major, established leaders in government, business and NGOs who influence policy and practice concerning pastoral development, climate change and conservation in their countries (Reid et al., 2014b, Reid interview). These former students are drawing from their experiences in our co-produced work, as well as many other influences in their lives, to make major changes in policy and practice. Pickering, describing the capacity of his pastoral team leader (who is not yet a graduate student), described it this way: "I'm very impressed with the individual he (our pastoral team leader) has become....how he takes an active role in his community. He has learned from conducting and advising our research project how research and discussions can be used to learn with community members. He has combined this with his social, environmental, herding, and pastoral insights into Samburu life to help others. He knows how to bring in all those perspectives and bring people together to identify research, understand the science, and solve bigger issues in his community." In the Colorado case, one of the students on the project is a rising star in governmentled science. Her prodigious experience in co-production and deep reflection on process will likely influence all her future work on government practice and science (Reid pers obs).

Another important process is the establishment and expansion of networks, which can be formal or informal. All our cases built and supported less formal social networks. Our Spanish case explicitly connected to and provided information to a more formal network of women pastoralists called Ganaderas en Red (GeR). Project leader Fernández-Giménez describes the impacts of their workshops: "Although they can't be attributed solely to this project, the workshops we facilitated with (the) GeR (network) helped strengthen women's networks, self-esteem/confidence, and clarify their agenda for action." In this case, the pastoral women who were part of the GeR network are very committed to broad-scale social transformation of food systems and rural communities. The team's research supported the network's goal by studying and raising the visibility and profile of women pastoralists as both tradition-keepers and change agents in rural livestock systems (Fernández-Giménez et al., 2019c, FernándezGiménez interview).

A few of our cases had the process goal to implement action. Our Colorado team focused all of their work on implementing a grazing experiment. Because other stakeholders see this experiment (and ranchers look over the fence at it), it is not a stretch to say they implemented action, and this is having outcomes. In East Africa and Mongolia, the action is mostly implemented by pastoral leaders whose capacity was built during the course of our co-produced research. In the East Africa case, pastoral community facilitators (many of whom were also getting advanced degrees on the project) worked closely with communities to bring in more drought resistant cattle breeds, new vaccines for East Coast fever and more sustainable water pumping technology. After they finished their community facilitation positions, one became a national NGO CEO, leading a community conservation governance revolution in Kenya (Reid et al., 2016a). Another pastoral leader was elected governor, designing and executing pastoral policy for a million pastoralists and then became a water minister for the country of Kenya (Reid et al., 2014b, Reid interview). While our co-produced work together is far from the cause of the major impacts of these pastoral leaders on their country, our work did contribute to building their confidence and allowing them to see the value and limits of research through their advanced degrees on our projects (Reid et al., 2014b). The outcomes and impacts of the implementation of these actions by SWS partnership participants are likely far-reaching.

\section{Intangible Impacts}

Kassam, the leader of the Pamir's case, makes a strong argument that impacts go beyond the tangible to the intangible (Lang et al., 2012) and the unanticipated, sometimes occurring faster than expected and stretching far into the future. Faster than expected impacts occurred in other cases of Kassam's work, where maps co-generated with the Sami people of NW Russia were immediately used by the Sami to stop a gold mine and ensure tourism was driven from local cultural perspectives [Kassam interview, (Robinson and Kassam, 1998; Kassam, 2009a)]. Iñupiat of Wainwright Alaska, also used a co-generated humanecological map of marine and land-use to control extraction activities of a major oil company (Kassam and WainwrightTraditional-Council, 2001; Kassam, 2009a). In the East Africa case, the Maasai team co-developed a land-use map that quickly became a boundary object to learn about and slow down 
rapid conversion of pastoral and wildlife land into an urban development (Reid et al., 2016b).

As for intangible impacts far into the future, Kassam said:

"The advantage of partnering is the work continues. So you can't anticipate the quantum ways in which the work will affect the future.... To be eligible for funding we need, we need to use the linear language of products, outputs and outcomes. However, in genuine transdisciplinary research where there is humility, trust, and mutual respect, there's this whole universe of the intangible and unanticipated. Of course, some of the unintended consequences may be negative, in which case the participatory approach with a transdisciplinary network is key for articulating an effective and immediate response. Furthermore, a participatory approach ensures a movement of that work beyond the lifetimes of the partners themselves. Increasingly our students come from the very communities we are working with, thus eliminating the divide between them and us. The work takes a life of its own, and it continues, even after the partners have passed on, because it permeates and evolves into different aspects of a community's life."

Of course, any type of impact, especially intangible impacts, are very difficult to measure or attribute to the partnership activities. And yet, the idea of intangible impacts resonated with several of our cases because of the impacts of pastoral leaders and the impacts of the scientists who know how to do collaborative work. It is easy to imagine that the work of pastoral leaders and scientists will ripple out into the future in ever expanding (but also attenuating) rings of influence. Of course, if these leaders create negative impacts, those will also ripple into the future. Here, causal attribution is impossible, but the SWS partnership made a "strong contribution" to this intangible impact.

\section{Are These Outcomes and Impacts Transformative?}

It is a big leap to go from describing outcomes and impacts to then describe them as transformative. Let us revisit the definition of transformation from above: the creation of "a fundamentally new system when ecological, economic, or social structures make the existing system untenable" (Walker et al., 2004): 5. While prior empirical work has focused on external drivers of transformation (Olsson et al., 2006), this series of case studies demonstrates outputs, outcomes and impacts that connect to the internal drivers of transformation (Meadows, 1999). We speculate that most co-produced work does not and will not lead to transformation directly, but instead builds institutional entrepreneurs, leads to social innovation, informs society and helps local to national actors to adapt more effectively and be more resilient in the face of change. For these projects to be transformative, there are many factors that would need to align, including external factors (Olsson et al., 2006), enduring social networks, and the power to put new insights into practice.

It is also a matter of discussion whether or not transformation of systems is a desirable goal, even though there are strong calls for transformation in the sustainability science community (Folke et al., 2002; Gunderson and Holling, 2002; Biggs et al., 2010; Westley et al., 2011; O’Brien, 2012; Moore et al., 2014). Obviously, all change, transformational or not, has political aspects and involves trade-offs of costs and benefits for different interest groups.
What makes an outcome and impact transformative? As we saw above, transformations occur when institutional entrepreneurs recognize when windows of opportunity open and know what leverage points and social innovations to use in those windows. Simply, the more fundamental the change caused by a leverage point, the more transformative it is. Fundamental changes are those that change the "underpinning values, goals, and world views of actors" by those who have the power to change the system's structure and institutions and the power to access information about the system (Abson et al., 2017):32. Indeed, these rangeland partnerships aim to make those fundamental changes by changing the paradigms about problems, how to solve them and who solves them. They also change the paradigm of science by shifting the power of expertise away from science alone to all knowledge keepers.

There is some evidence that the process used by some of our cases coincided with the opening of windows of opportunity in national political cycles to allow some of our cases to contribute to major system transformations in policy, which then may have transformed society. In these cases, the co-produced research did not cause society to transform. Instead, the research, at the right time and with the right partners, helped other efforts catalyze and accelerate transformations already underway. This occurred in our East Africa case when development and implementation of a new national constitution in 2013 provided this window of opportunity. Here, the project facilitators and other researchers were asked to participate in task forces to develop the new Wildlife Act associated with the new constitution. The team was able to put into place fundamental changes that now allow pastoral communities to lead and manage community conservancies for the benefit of pastoral livelihoods and wildlife conservation for the first time.

In other cases, the window of opportunity for policy changes was not yet open, and thus the work provides foundational groundwork that may help catalyze and accelerate change in the future. In our Mongolia case, the project assessed the social and ecological outcomes of community-based institutions. And historical work by the leader of the Mongolia case addressed pastoral mobility, land tenure and community response to disaster. The leader and former Mongolian students have brought this knowledge to many policy fora over the last decade, but this has not resulted in a major change in pastoral land policy, probably because the window of opportunity to implement the law has not opened yet.

Capacity building through the partnership experience also transforms participating scientists. The leader of our Spain and Mongolian cases, Fernández-Giménez said, "For me the relationships that are developed through partnerships are a microcosm of the relationships we need to build in our society to overcome the false divides between academic and community member, between environmentalist and livestock producer, etc. Only through engaging with each other as whole people, building empathy, trust and a shared vision for the future will we address our environment, livelihood and social issues. Because I am an academic, to strengthen the process I go back to how we train the next generation of researchers, conservationists and even producers (if they obtain formal education). Collaboration must 
be part of the curriculum and co-production should become how we do applied research in natural resources and conservation" (Fernández-Giménez interview).

The importance of transformative learning cannot be overemphasized. "For transformative learning to occur, this disorienting dilemma must invoke a period of reflection for each participant on how these new concepts, mutual dependencies, data, and methodologies fit together, which may lead to a revision of their existing mental models (i.e., critical reflection)...." (Pennington et al., 2013): 570. This type of learning can have far reaching effects, even transforming power structures and regulatory frameworks (Pahl-Wostl, 2009; Moore et al., 2014).

\section{Are These SWS Partnerships Transforming the Way We Do Science?}

We think the partnerships described here are also transforming how we do science and its impacts on society. Research that uses more SWS principles are able to leverage more diverse process outputs and have potential to make more change across more impact pathways (Belcher et al., 2019). In addition to having more impact, we suggest that our SWS partnerships are changing the very process of science through co-production and knowledge integration, who is included as part of science and thus the power structure of science. This new science is not driven by the theories and ideas of science alone, rather the problem at hand is the centerpiece on the "learning table" surrounded by the people who most directly face the problem (like pastoralists, ranchers). This evolution in science is most prevalent in practical and problem oriented fields dealing with complex problems like public health, development, and sustainability (Belcher et al., 2019).

\section{CROSS-CASE ANALYSIS AND THE PECULIARITY OF RANGELAND'S PARTNERSHIPS}

We can now hypothesize how different biophysical, socialeconomic and historical partnership characteristics of each case affected the form and performance of each SWS partnership. Our cases differ the most in their country's values of the Human Development Index (Table 1). The HDI varies positively with the number of years of education, life expectancy, and per capita income (UNDP, 2019). We hypothesize that pastoralists from cases in medium to low HDI countries (Kenya, Tanzania, Tajikistan and Afghanistan) and where there is an institutional vacuum (many, including Mongolia) have more need to develop local and innovative solutions, to use researchers to access and affect policy, and to implement pastoral development actions. Support for these patterns exist in our data but is not strong. For example, the women pastoralists in Spain had to innovate new institutional relationships in order to access grazing land and other needed resources (Fernández-Giménez et al., 2019c). In the US case, many researchers have access to policy makers, and thus while this connection is not explicit in our description of the CARM case, it still exists. For example, CARM was incorporated into the US National Climate Assessment, Northern Great Plains chapter as an example of climate adaptive management.
In relation to the role of partnership history, these cases strongly rely on pre-existing relationships between the research team (or key team members) and the communities, and the overall research team approach and openness to a different set of goals and methods. This last variable may be more important that either biophysical or social-economic variables.

Also important may be the general area of governance and policy, specifically the relative dominance of different types of land tenure and thus the relative security of pastoral ownership and access to rangelands (Table 1). We did not measure this, so our values in Table 1 are best guesses. Generally, we observe more private land ownership in the CARM, Spain and Kenya cases than in the others. In the Kenyan case, however, private land is often supported by access to large areas of public land, and thus much of the grazing land is not fully secure for pastoral use. In the CARM and Spanish cases, there may be less opportunity for powerful interests to grab land and thus, perhaps, less pastoral need to use research partnerships to help push back on government or corporate power.

We also hypothesize that cases far from centers of power may have stronger partnerships because pastoralists, again, need to use research to empower their voices with central or regional government. This variable was difficult to measure in our cases, since many cases (Kenya, Reto, MOR2, and Spain) worked in multiple locations that varied from remote extensive rangelands to peri-urban rangelands. We also found no obvious differences in our partnership according to the strong differences in rainfall or project area size in Table 1.

This chapter is about partnerships, but particularly those in rangelands. Is there anything special about these partnerships in this environment and with pastoral peoples? We think so for two main reasons. First, we think that partnerships may be particularly innovative in pastoral lands because pastoral people and rangelands are so marginalized and thus must make do with what they have at hand. Second, in analyzing our cases, we argued that rangelands with common property regimes and pastoral populations with lower human development indices may also particularly welcome researchers as partners, in an attempt to reduce asymmetries of power with powerful, nonpastoral actors. This notion is supported by the fact that several of our cases in these situations focused on developing research information with communities to bring to national policy makers to encourage those in power to develop more pro-pastoral policies.

\section{RECURRING CHALLENGES AND THE FUTURE}

\section{Recurring Challenges}

These approaches come with a raft of recurring challenges, dangers and potential negative pathways. For example, as mentioned above (Chambers et al., in review), found that those cases that focused on how knowledge is produced during coproduction did this at the expense of other outcomes. To achieve outcomes, there needs to be full engagement in the action part of the adaptive learning cycle in Figure 2. 
Participants in our cases saw a whole range of additional challenges. Many were things "we wished we knew at the start" which are recommendations to others taking these approaches. Wilmer, who participated in the Colorado case study said: "I would advise a new team to engage in team science and transdisciplinary science, engage with the literature, go through a process to think carefully about the lessons already learned and how you will evaluate your work."

One of the most difficult challenges is wrestling with who to include and who to leave out in these partnerships. It is important that the initial team does not include only people already familiar to the partnership's leaders (Wilmer interview). Careful thought should be given to the level of power that the participants have in their home institutions' hierarchy, so that there is some prospect of accessing the levers of power (Wilmer, Reid interviews). In other cases, partnerships may want to avoid inviting participants who have too much power, usually from government, so that these actors do not inadvertently disempower marginalized pastoralists (Kassam, Reid interviews).

These partnerships are also complex and require significant time commitments. As seen in Figure 3, moving from interdisciplinary (inner ring), to transdisciplinary (middle ring) to transformative (outer ring) science involves more and more complexity and time. It is also operationally complex. Wilmer said, "We struggle with the complexity of this project. There is a clear need for project coordinators in this work, everyone else has to fill multiple roles over time. Need doers and thinkers and dreamers, need a well-balanced team. For the leaders, it has to be OK not to know stuff." And time is always in short supply among participants, so it helps if they are proud of their role and if participants have aligned incentives, values and interests (Wilmer interview). Time availability is an issue also in terms of project and partnership setting. Usual funding for research projects, at least in Europe, is 2-4 years, which is usually not sufficient to fully implement an adaptive co-generation arena for this work.

There is also hidden bias and naivete on the part of participating scientists. When working in many former or current lands of Indigenous peoples in many parts of the world, there is an underlying history of colonialism and often cultural genocide. Biophysical scientists, in particular, tend to ignore or be ignorant of this history. It then becomes incumbent on team members who are Indigenous Peoples or community members, or those trained in social science or the humanities to explain the situation to the biophysical scientists and explain why certain actions, questions or practices will trigger the pain of this history for community members (Kassam interview). In addition, biophysical scientists often think they are entirely neutral about the subjects they are working on, which they are not. For example, Wilmer from the Colorado team said, "We self-facilitate, so we made a rule that the scientist involved in an issue is not allowed to facilitate discussion that they feel passionate about." Social scientists have biases too. For example, their models of social relationships may not be backed by data and may be wrong (Wilmer interview).

Moreover, interdisciplinary scientists still do not have an easy fit within traditional academic systems in many countries (e.g.,
Spain). Early career researchers who are pursuing such pathways (very frequently women) require extra-training and experience to navigate between disciplines, knowledge systems and languages, and face precariousness for years while struggling to find a place in natural sciences or humanities departments, which hinders their involvement in SWS processes.

There is also a real potential that partnerships can results in unintended negative outcomes. If a co-production process strengthens oppressive power structures, the process will likely hurt local participants (Wilmer interview). Scientists have to be ready for decision makers to cherry pick their results and make decisions on single facts that are not supported by the general conclusions of their study. For example, a large modeling study in Tanzania showed that human population growth and expansion of small maize fields in a multiple use conservation area had little overall impact on wildlife populations. But one line in the report described what could happen if the cropland expanded dramatically. This one line was used by political appointees to justify putting a moratorium on crop cultivation by any pastoral family in the conservation area (Reid interview).

Finally, there just is not enough evaluation of these SWS partnerships (Wiek et al., 2014; Belcher et al., 2019). Wilmer said, "There is a whole science of evaluation for doing this efficiently and effectively. There are many, many different methods and approaches. In our case, self-reflection has been very valuable. Fernandez-Gimenez said, 'It's not yet clear to me what impacts, if any, can be traced directly to our partnership approach in this project, (but it did lead to)... several of the women pastoralists ...participating in a high-level side event at COP 25 (the UN Framework Convention on Climate Change in Madrid in 2019).”

\section{The Future: Transformative Science With Society As the Models of Science Change, What Is SWS Research Then Becoming?}

It is becoming research that challenges most of our conventional wisdom about how science should be done, is entirely redefining the boundaries of science, leads to unexpected insights into how to do science and how to have impact on the world's most challenging problems with science. It is also more than this. It turns out that this is exactly how the US National Science Foundation (NSF) defines "transformative science," but their only examples have to do with cutting edge scientific discovery. Science with society and transdisciplinary research are evolving into a form of transformative science that is much beyond what NSF is now describing because it requires full engagement and innovation with society, which calls on scientists to deal with much more complexity than when they work alone on a problem. If NSF's transformative science definition is describing "hard science" discovery, then science with society is "difficult and complex science" discovery.

Science with society is now rapidly evolving into a new type of science as demonstrated by our SWS partnerships in rangelands. We call this transformative science with society and it has at least the following features. 
We think there are a number key changes that need to occur in this transformation of science. First, as described above, there is a need to move this type of work so that action and science are on equal footing. Our rangelands partnerships demonstrate different approaches to doing this from experimenting with management practices in Colorado to including people who pursue action as part of the core team (community and policy facilitators, East Africa). The next evolution, already taking place, is leadership and agenda setting of SWS teams by pastoralists or conservation practitioners or government managers. In many cases, research may not be part of these partnerships initially, brought in later to evaluate a process, even though this is not ideal.

A second systems transformations needed in western science are efforts to decolonize how western science is done, so it is more inclusive of and driven by non-western ways of inquiry and knowing, especially in the area of the environment. Key here is drawing on Indigenous science and resource management models (Pickering Sherman and Sherman, 2010) and decolonizing western scientific methodologies (Smith, 2002). This also means breaking down the cultural myth of pristine landscapes in conservation, for example (Gilio-Whitaker, 2019). True decolonization, in countries settled by colonists, has to reach deep enough to address the issue of land, power and privilege, and whose worldviews "get to count" as knowledge and research (Tuck and Yang, 2012). It also means addressing power inequities in western science and conservation (Willow, 2015).

Thirdly, there needs to be more focus on power and its role in SWS partnerships. Many scholars and practitioners recognize that this approach needs to give more attention to power (Brandt et al., 2013; Cornell et al., 2013; Schuttenberg and Guth, 2015; Miller and Wyborn, 2018; Knapp et al., 2019). This means understanding "how power is used, expressed and practiced" (Knapp et al., 2019):8. This starts with navigating the power between team members within science, within practice and also between science and practice. It also involves considering who leads the SWS partnership and how knowledge is integrated (Knapp et al., 2019). It also means understanding who has the power to make change at what level of scale. Knapp et al. (2019) found that approaches that focus more on action pay more attention to power and power sharing is greater in projects that focus on the local rather than broader scales.

If this science is to be transformative, it needs more focus on systems transformations science. As described above, much new focus is on how systems transform. Key here is when institutional entrepreneurs recognize the opening of windows of opportunity and if they know what leverage points and social innovations to use in those windows. This approach is in its infancy, but will strongly inform this evolution in SWS research, allowing targeted action to transform systems. None of our cases explicitly used transformations science in their work.

Another need is more focus on the moral/ethical aspects of this work. The scholarship of these partnerships is replete with moral statements about societal change, justice, inclusion and equitability. We expect these aspects to be more prominent in this work in the future.

Also, we all need to become students of knowledges, epistemology and mental models. Our Colorado case highlights the importance of epistemology and mental models (FernándezGiménez et al., 2019b). We expect that this foundational insight will become even more important in future work. All of our cases changed mental models of participants, but only a few recorded and evaluated these changes.

Transformative learning is clearly at the core of this approach to science. It is also clear that social and particularly transformative, triple loop learning is foundational to this new evolution of SWS research. The focus will likely be on how changes in participant's (including researcher's) understanding of themselves occur, how they revise their belief systems and how they change their behaviors [e.g., (Mezirow, 1991)].

We can also see the need for more focus on intangible and long-term impacts and their evaluation. It is clear in our cases that long-term engagement through a SWS partnership is the foundation of long-term (and sometimes intangible) impacts. These partnership just don't fit a short-term "project" model very well. Those partnerships that extend into the future should continue to yield more lessons about impacts, but only if they are rigorously evaluated against achievement of both tangible and intangible outcomes.

Finally, critical self-assessment, which addresses the different and differential social positions, power and epistemologies of participants, is needed in all collaborative partnerships. And, as described above, the future of this science needs better evaluation and, perhaps, may achieve more solid attribution. This will also improve research design and implementation (Belcher et al., 2019). Chief hurdles in this evaluation is the complexity of the multiple impact pathways of this work and the difficulty of identifying a "counterfactual comparator." Belcher et al. (2019) suggest the best approach is theory-based evaluation, using tools like a theory of change. In our cases, some employed robust reflective evaluations on team process and also as part of training sessions.

Finally, all of our interviewees recognized the difficulty and challenges in doing this work. And yet, they all are deeply invested in continuing this approach, partly because it has a deep moral aspect to its process. Clearly, science as a process has deep cultural elements, some that are inclusive and some that are less inclusive. The teams here are on a discovery pathway to magnify the inclusive nature of science and learning together.

\section{AUTHOR CONTRIBUTIONS}

RR led the interviews \& data analysis. RR, MF-G, HW, TP, K-AK, LMP, JD, KJ, CJ, TU, EO-R, FR, and CK wrote the paper. RR, MF-G, HW, TP, K-AK, and LMP participated in interviews. RR, MF-G, TP, K-AK, JD, DN, EO-R, FR, and CK led a partnership team. RR, HW, LMP, KJ, CJ, TU, DK, and AY participated on a partnership team. All authors contributed to the article and approved the submitted version.

\section{ACKNOWLEDGMENTS}

We thank the many pastoral and rancher families and communities who have welcomed us into their lives and their 
homes and shared their food, thoughts and wisdom with us. We also thank the many funders who supported this work over the decades, who are individually acknowledged in each of our project papers cited here. We add one new specific acknowledgment here: EO-R has been funded by Juan de la

\section{REFERENCES}

Abbink, J. (2011). 'Land to the foreigners': economic, legal, and socio-cultural aspects of new land acquisition schemes in Ethiopia. J. Contemp. Afr. Stud. 29, 513-535. doi: 10.1080/02589001.2011.603213

Abson, D. J., Fischer, J., Leventon, J., Newig, J., Schomerus, T., Vilsmaier, U., et al. (2017). Leverage points for sustainability transformation. Ambio 46, 30-39. doi: 10.1007/s13280-016-0800-y

Agrawal, A. (1995). Dismantling the divide between indigenous and scientific knowledge. Dev. Change. 26, 413-439. doi: 10.1111/j.1467-7660.1995.tb00560.x Agrawal, A. (2002). "Common resources and institutional sustainability," in Drama of the Commons, ed E. Ostrom (Washington, DC: National Academy Press).

Akama, J. S., Lant, C. L., and Burnett, G. W. (1996). A political-ecology approach to wildlife conservation in Kenya. Environ. Values 5, 335-347. doi: $10.3197 / 096327196776679276$

Alden Wiley, L. (2011). The Tragedy of Public Lands: The Fate of the Commons Under Global Commercial Pressure. Rome: International Land Coalition. Available online at: www.iccaconsortium.org/wp-content/uploads/2015/08/legal-examplethe-tragedy-of-public-lands-2011.pdf

Asner, G. P., Elmore, A. J., Olander, L. P., Martin, R. E., and Harris, A. T. (2004). Grazing systems, ecosystem responses, and global change. Annu. Rev. Environ. Resour. 29, 261-299. doi: 10.1146/annurev.energy.29.062403.102142

Barry, S., Schohr, T. K., and Sweet, K. (2007). The California Rangeland conservation coalition: grazing research supports an alliance for working landscapes. Rangelands 29, 31-34. doi: 10.2111/1551-501X(2007)29(31:TCRCC)2.0.CO;2

Belcher, B. M., Clausa, R., Davela, R., and Ramireza, L. F. (2019). Linking transdisciplinary research characteristics and quality to effectiveness: a comparative analysis of five research-for-development projects. Environ. Sci. Policy 101, 192-203. doi: 10.1016/j.envsci.2019.08.013

Belsky, J. M., and Barton, A. (2018). Constitutionality in Montana: a decade of institution building in the blackfoot community conservation area. Hum. Ecol. 46, 79-89. doi: 10.1007/s10745-018-9967-0

Beratan, K. K. (2014). Summary: addressing the interactional challenges of moving collaborative adaptive management from theory to practice. Ecol. Soc. 19:46. doi: 10.5751/ES-06399-190146

Berkes, F. (ed.). (1999). Sacred Ecology: Traditional Ecological Knowledge and Resource Management. Philadelphia, PA: Taylor and Francis.

Berkes, F. (2009). Indigenous ways of knowing and the study of environmental change. J. R. Soc. N. Z. 39, 151-156. doi: 10.1080/03014220909510568

Biggs, R., Westley, F. R., and Carpenter, S. R. (2010). Navigating the back loop: fostering social innovation and transformation in ecosystem management. Ecol. Soc. 15:9. doi: 10.5751/ES-03411-150209

Borras, S. M., and Franco, J. C. (2012). Global land grabbing and trajectories of agrarian change: a preliminary analysis. J. Agrarian Change 12, 34-59. doi: 10.1111/j.1471-0366.2011.00339.x

Brandt, P., Ernst, A., Gralla, F., Luederitz, C., Lang, D. J., Newig, J., et al. (2013). A review of transdisciplinary research in sustainability science. Ecol. Econ. 92, 1-15. doi: 10.1016/j.ecolecon.2013.04.008

Brick, P., Snow, D., and Van De Wetering, S. (2001). Across the Great Divide: Explorations in Collaborative Conservation and the American West. Washington, DC: Island Press.

Briske, D. D., Fuhlendor, S. D., and Smeins, E. E. (2005). State-and-transition models, thresholds, and rangeland health: a synthesis of ecological concepts and perspectives. Rangeland Ecol. Manag. 58, 1-10. doi: 10.2111/15515028(2005)58<1:SMTARH >2.0.CO;2

Briske, D. D., Sayre, N. F., Huntsinger, L., Fernandez-Gimenez, M., Budd, B., and Derner, J. D. (2011). Origin, persistence, and resolution of the rotational grazing
Cierva Incorporation Fellowship of the Ministry of Science, Innovation and Universities (IJCI-2017-34334). We also thank, in advance, the next generation of leaders who will remake this kind of work in their own vision to make change in the world.

debate: integrating human dimensions into rangeland research. Rangeland Ecol. Manag. 64, 325-334. doi: 10.2111/REM-D-10-00084.1

Bruegger, R. A., Jigjsuren, O., and Fernandez-Gimenez, M. E. (2014). Herder observations of rangeland change in Mongolia: indicators, causes, and application to community-based management. Rangeland Ecol. Manage. 67, 119-131. doi: 10.2111/REM-D-13-00124.1

Bryant, R. L. (1992). Political ecology - an emerging research agenda in third-world studies. Polit. Geogr. 11, 12-36. doi: 10.1016/0962-6298(92)90017-N

Campbell, D. J., Lusch, D. P., Smucker, T. A., and Wangui, E. E. (2005). Multiple methods in the study of driving forces of land use and land cover change: a case study of Se Kajiado District, Kenya. Hum. Ecol. 33, 763-794. doi: 10.1007/s10745-005-8210-y

Cash, D. W., Adger, W. N., Berkes, F., Garden, P., Lebel, L., Olsson, P., et al. (2006). Scale and cross-scale dynamics: governance and information in a multilevel world. Ecol. Soc. 11:8. doi: 10.5751/ES-01759-110208

Cash, D. W., Clark, W. C., Alcock, F., Dickson, N. M., Eckley, N., Guston, D. H., et al. (2003). Knowledge systems for sustainable development. Proc. Natl. Acad. Sci. U.S.A. 100, 8086-8091. doi: 10.1073/pnas.1231332100

Chambers, J. M., Wyborn, C., Ryan, M., Reid, R. S., Riechers, M., Serban, A., et al. (in review). Collaborating for sustainability: navigating purpose, power, politics, and pathways. Nat. Sustain.

Charnley, S., Sheridan, T. E., and Nabhan, G. P. (2014). Stitching the West Back Together: Conservation of Working Landscapes. Chicago, IL: University of Chicago Press. doi: 10.7208/chicago/9780226165851.001.0001

Cleaver, F. (2012). Development Through Bricolage: Rethinking Institutions for Natural Resource Management. Abingdon: Routledge.

Conley, A., and Moote, A. (2001). Collaborative Conservation in Theory and Practice: A Literature Review, Tucson, Udall Center For Studies In Public Policy. University of Arizona, Tuscon

Cook, J. A., and Fonow, M. M. (1985). Knowledge and women's interests: issues of epistemology and methodology in feminist sociological research. Sociol. Inq. 56, 2-29. doi: 10.1111/j.1475-682X.1986.tb00073.x

Cornell, S., Berkhout, F., Tuinstra, W., David Tabara, J., Jaeger, J. Chabay, I., et al. (2013). Opening up knowledge systems for better responses to global environmental change. Environ. Sci. Policy 28, 60-70. doi: 10.1016/j.envsci.2012.11.008

DĨaz, S., Settele, J., Brondizio, E., Ngo, H. T., Agard, J., Arneth, A., et al. (2019). Pervasive human-driven decline of life on earth points to the need for transformative change. Science 366:eaax3100. doi: 10.1126/science.aax3100

Dressler, W., Buescher, B., Schoon, M., Brockington, D., Hayes, T., Kull, C. A., et al. (2010). From hope to crisis and back again? a critical history of the global $\mathrm{Cb}$ nrm narrative. Environ. Conserv. 37, 5-15. doi: 10.1017/S03768929100 00044

Earl, S., Carden, F., and Smutylo, T. (2001). Outcome Mapping: Building Learning and Reflection Into Development Programs. Ottawa, ON: International Development Research Centre (IDRC).

Ellis, J. E., and Swift, D. (1988). Stability of African pastoral ecosystems: alternate paradigms and implications for development. J. Range Manag. 41, 450-459. doi: $10.2307 / 3899515$

England, K. (1994). Getting personal: reflexivity, positinoality, and feminist research. Profession. Geogr. 46, 80-89. doi: 10.1111/j.0033-0124.1994. 00080.x

Espeland, E. K., Schreeg, L., and Porensky, L. M. (2020). Managing risks related to climate variability in rangeland-based livestock production: what producer driven strategies are shared and prevalent across diverse dryland geographies? J. Environ. Manage. 255:109889. doi: 10.1016/j.jenvman.2019.109889

Fernández-Giménez, M. E. (1999a). Reconsidering the role of absentee herd owners: A view from Mongolia. Hum. Ecol. 27, 1-27. doi: $10.1023 / \mathrm{A}: 1018757632589$ 
Fernández-Giménez, M. E. (1999b). Sustaining the steppes: a geographical history of pastoral land use in Mongolia. Geogr. Rev. 89, 315-342. doi: 10.1111/j.1931-0846.1999.tb00222.x

Fernández-Giménez, M. E., A., Allegretti, A., Angerer, J., Baival, B., Batjav, B., et al. (2019a). "Sustaining interdisciplinary collaboration across continents and cultures: lessons from the Mongolian rangelands and resilience project," in Collaboration Across Boundaries for SocialEcological Systems Science: Experiences Around the World, ed S. Perz (Cham: Palmgrave Macmillan).

Fernández-Giménez, M. E., Augustine, D., Porensky, L., Wilmer, H., Derner, J., Briske, D., et al. (2019b). Complexity fosters learning in collaborative adaptive management. Ecol. Soc. 24:29. doi: 10.5751/ES-10963-240229

Fernández-Giménez, M. E., Batkhishig, B., Batbuyan, B., and Ulambayar, T. (2015). Lessons from the dzud: community-based rangeland management increases the adaptive capacity of Mongolian herders to winter disasters. World Dev. 68, 48-65. doi: 10.1016/j.worlddev.2014.11.015

Fernández-Giménez, M. E., and Estaque, F. F. (2012). Pyrenean pastoralists' ecological knowledge: documentation and application to natural resource management and adaptation. Hum. Ecol. 40, 287-300. doi: 10.1007/s10745-012-9463-x

Fernández-Giménez, M. E., Oteros-Rozas, E., and Ravera, F. (2019c). Co-Creating Knowledge For Action With Women Pastoralists in Spain. Fort Collins, CO; Cataluyna: Colorado State University; Universitat Vic.

Fernández-Giménez, M. E., Venable, N. P., Angerer, J. P., Fassnacht, S. R., Reid, R. S., and Jamiyansharav, K. (2017). Exploring linked ecological and cultural tipping points in Mongolia. Anthropocene 17, 46-69. doi: 10.1016/j.ancene.2017.01.003

Fernández-Giménez, M. E., Wang, X., Batkhishig, B., Klein, J. A. and Reid, R. S. (eds.). (2012). Restoring Community Connections to the Land: Building Resilience Through Community-Based Rangeland Management in China and Mongolia. Wallingford: Cabi. doi: 10.1079/9781845938949.0000

Fischer, J., and Riechers, M. (2019). A leverage points perspective on sustainability. People Nat. 1, 115-120. doi: 10.1002/pan3.13

Fiske, S. J., Crate, S. A., Crumley, C. L., Galvin, K. A., Lazrus, H., Luber, G., et al. (2014). Changing the Atmosphere: Anthropology And Climate Change. Arlington, VA: American Anthropological Association.

Folke, C., Carpenter, S., Elmqvist, T., Gunderson, L., Holling, C. S., and Walker, B. (2002). Resilience and sustainable development: building adaptive capacity in a world of transformations. Ambio 31, 437-440. doi: 10.1579/0044-7447-31. 5.437

Folke, C., Carpenter, S. R., Walker, B. H., Scheffer, M., Chapin, F. S. I., and Rockstrom, J. (2010). Resilience thinking: integrating resilience, adaptability and transformability. Ecol. Soc. 15:20. doi: 10.5751/ES-03610150420

Galvin, K. A. (2009). Transitions: pastoralists living with change. Annu. Rev. Anthropol. 38, 185-198. doi: 10.1146/annurev-anthro-091908-164442

Gilio-Whitaker, D. (2019). As Long as Grass Grows (Boston, MA: Beacon Press)

Goldman, M. L. (2006). Sharing Pastures, Building Dialogues: Maasai and Wildife Conservation in Northern Tanzania (Ph.D. thesis), University of Wisconsin, Madison, WI.

Gosnell, H., Haggerty, J. H., and Travis, W. R. (2006). Ranchland ownership change in the Greater Yellowstone ecosystem. 1990-2001: implications for conservation. Soc. Natl. Resour. 19, 743-758. doi: 10.1080/08941920600801181

Greenwood, D., and Levin, M. (2007). Introduction to Action Research. New York, NY: Sage Publications. doi: 10.4135/9781412984614

Gunderson, L., and Holling, C. (eds.). (2002). Panarchy: Understanding Transformations in Human and Natural Systems. Washington, DC: Island Press.

Guston, D. H. (1999). Stabilizing the boundary between us politics and science: the role of the office of technology transfer as a boundary organization. Soc. Stud. Sci. 29, 87-111. doi: 10.1177/030631299029001004

Guston, D. H. (2001). Boundary organizations in environmental policy and science: an introduction. Sci. Technol. Hum. Values 26, 399-408. doi: $10.1177 / 016224390102600401$

Hadorn, H. G., Bradley, D., Pohl, C., Stephan, R., and Wiesmann, U. (2006). Implications of transdisciplinarity for sustainability research. Ecol. Econ. 60, 119-128. doi: 10.1016/j.ecolecon.2005.12.002
Haraway, D. (1988). Situated knowledges: the science question in feminism and the privilege of partial perspective. Feminist Stud. 14, 575-599. doi: $10.2307 / 3178066$

Haraway, D. (1991). Simians, Cyborgs and Women: The Reinvention of Nature. New York, NY: Routledge.

Harcourt, W., and Nelson, I. L. (2015). Practicing Feminist Political Ecologies: Moving Beyond the 'Green Economy'. London: Zed Books.

Harmon, D. (2002). In Light of Our Differences: How Diversity in Nature and Culture Makes us Human. Washington, DC: Smithsonian Institution Press.

Heikkila, T., and Gerlak, A. K. (2019). Working on learning: how the institutional rules of environmental governance matter. J. Environ. Plann. Manag. 62, 106-123. doi: 10.1080/09640568.2018.1473244

Herrick, J. E., Brown, J. R., Bestelmeyer, B. T., Andrews, S. S., Baldi, G., Davies, J., et al. (2012). Revolutionary land use change in the 21st century: is (Rangeland) science relevant? Rangeland Ecol. Manag. 65, 590-598. doi: 10.2111/REM-D-11-00186.1

Hillis, V., Berry, K. A., Swette, B., Aslan, C., Barry, S., and Porensky, L. M. (2020). Unlikely alliances and their implications for resource management in the American west. Environ. Res. Lett. 15:045002. doi: 10.1088/1748-9326/ab6fbc

Huisman, K. (2008). Does this mean you're not going to come visit me anymore?: an inquiry into an ethics of reciprocity and positionality in feminist ethnographic research. Sociol. Inq. 78, 372-396. doi: 10.1111/j.1475-682X.2008.00244.x

Huntsinger, L., Forero, L. C., and Sulak, A. (2010). Transhumance and pastoralist resilience in the Western United States. Pastoralism 1, 9-36

IPBES (2019). Summary for Policymakers of the Global Assessment Report on Biodiversity and Ecosystem Services of the Intergovernmental Science-Policy Platform on Biodiversity and Ecosystem Services, eds S. Díaz, J. S. E. S. Brondízio, H. T. Ngo, M. Guèze, J. Agard, A. Arneth, P. Balvanera, K. A. Brauman, S. H. M. Butchart, K. M. A. Chan, L. A. Garibaldi, K. Ichii, J. Liu, S. M. Subramanian, G. F. Midgley, P. Miloslavich, Z. Molnár, D. Obura, A. Pfaff, S. Polasky, A. Purvis, J. Razzaque, B. Reyers, R. Roy Chowdhury, Y. J. Shin, I. J. Visseren-Hamakers, K. J. Willis, and C. N. Zayas. Bonn: IPBES Secretariat.

Jamsranjav, C., Fernandez-Gimenez, M. E., Reid, R. S., and Adya, B. (2019). Opportunities to integrate herders' indicators into formal rangeland monitoring: an example from Mongolia. Ecol. Appl. 29:e01899. doi: 10.1002/eap.1899

Jamsranjav, C., Reid, R. S., Fernández-Giménez, M. E., Tsevlee, A., Yadamsuren, B., and Heiner, M. (2018). Applying a dryland degradation framework for rangelands: the case of Mongolia. Ecol. Appl. 28, 622-642. doi: 10.1002/eap.1684

Jones, N. A., Ross, H., Lynam, T., Perez, P., and Leitch, A. (2011). Mental models: an interdisciplinary synthesis of theory and methods. Ecol. Soc. 16:46. doi: 10.5751/ES-03802-160146

Kassam, K.-A. (2009a). Biocultural Diversity and Indigenous Ways of Knowing: Human Ecology in the Arctic Calgary, Alberta: University of Calgary Press.

Kassam, K.-A., Bulbulshoev, U., and Ruelle, M. (2011). Ecology of time: calendar of the human body in the Pamir mountains. J. Persianate Stud. 4, 144-170. doi: 10.1163/187471611X600369

Kassam, K.-A., and Wainwright-Traditional-Council (2001). Passing on the Knowledge: Mapping Human Ecology in Wainwright, Alaska, Calgary. Alberta: Arctic Institute of North America.

Kassam, K. A. (2009b). Viewing change through the prism of indigenous human ecology: findings from the Afghan and Tajik Pamirs. Hum. Ecol. 37, 677-690. doi: 10.1007/s10745-009-9284-8

Kassam, K. A. S. (2010). Pluralism, resilience, and the ecology of survival: case studies from the Pamir mountains of Afghanistan. Ecol. Soc. 15:8. doi: 10.5751/ES-03485-150208

Kassam, K. A. S., Ruelle, M. L., Samimi, C., Trabucco, A., and Xu, J. C. (2018). Anticipating climatic variability: the potential of ecological calendars. Hum. Ecol. 46, 249-257. doi: 10.1007/s10745-018-9970-5

Keen, M., Brown, V. A., and Dyball, R. (2005). "Social learning: a new approach to environmental management," in Social Learning in Environmental Management: Towards a Sustainable Future. (Abingdon: Earthscan)

Kerven, C. (2003). "Agrarian reform and privatisation in the wider asian region: comparison with Central Asia," in Prospects For Pastoralism in Kazakstan and Turkmenistan: From State Farms to Private Flocks, eds C. Kerven (New York, NY: Routledge Curzon). 
Klein, J. T. (1990). Interdisciplinarity: History, Theory and Practice. Detroit: Wayne State University Press.

Klein, J. T. (2001). "The discourse of transdisciplinarity: an expanding global field," in Transdisciplinarity: Joint Problem Solving Among Science, Technology and Society, eds J. T. Klein, W. Grossenbacher-Mansuy, R. Haberli, A. Bill, R. W. Scholz, and M. Welti (Basel: Springer). doi: 10.1007/978-3-0348-8419-8

Klein, J. T. (2009). "Unity of knowledge and transdisciplinarity: contexts of definition, theory and the new discourse of problem solving," in Unity of Knowledge (In Transdisciplinary Research for Sustainability), eds G. Hirsch Hadorn, C. S. Pohl, and M. Scheringer (Paris: Unesco-Eolss).

Knapp, C. N., Reid, R. S., Fernández-Giménez, M. E., Klein, J. A., and Galvin, K. A. (2019). Placing transdisciplinarity in context: a review of approaches to connect scholars, society and action. Sustainability 11:4899. doi: 10.3390/su1118 4899

Knight, R. L., and White, C. (2009). Conservation for a New Generation: Redefining Natural Resources Management. Washington, DC: Island Press.

Knight, R. L. (2010). "The great awakening: transitioning from top-down to bottom-up conservation," in Managing Agricultural Landscapes for Environmental Quality Ii: Achieving More Effective Conservation, eds P. Nowak and M. Schnepf (Ankeny: Soil And Water Conservation Society), 101-106.

Koontz, T. M., and Thomas, C. W. (2006). What do we know and need to know about the environmental outcomes of collaborative management? Public Admin. Rev. 66, 111-121. doi: 10.1111/j.1540-6210.2006. 00671.x

Lang, D. J., Wiek, A., Bergmann, M., Stauffacher, M., Martens, P., Moll, P., et al. (2012). Transdisciplinary research in sustainability science: practice, principles, and challenges. Sustain. Sci. 7, 25-43. doi: 10.1007/s11625-0110149-x

Lemos, M. C., Arnott, J. C., Ardoin, N. M., Baja, K., Bednarek, A. T., Dewulf, A., et al. (2018). To co-produce or not to co-produce. Nat. Sustain. 1, 722-724. doi: 10.1038/s41893-018-0191-0

Maffi, L. (2001). On Biolcultural Diversity: Linking Languages, Knowledge, and the Environment. Washington, DC: Smithsonian Institution Press.

Mauser, W., Klepper, G., Rice, M., Schmalzbauer, B. S., Hackmann, H., Leemans, R., et al. (2013). Transdisciplinary global change research: the co-creation of knowledge for sustainability. Curr. Opin. Environ. Sustain. 5, 420-431. doi: 10.1016/j.cosust.2013.07.001

Max-Neef, M. A. (2005). Foundations of transdisciplinarity. Ecol. Econ. 53, 5-16. doi: 10.1016/j.ecolecon.2005.01.014

McDonald, W. (2002). "The malpai borderlands: building the 'radical center," in Ecosystem Management: Adaptive, Community-Based Conservation, eds G. K. Meffe, L. A. Nielsen, R. L. Knight, and D. A. Schenborn (Washington, DC: Island Press).

McNie, E. C. (2007). Reconciling the supply of scientific information with user demands: an analysis of the problem and review of the literature. Environ. Sci. Policy 10, 17-38. doi: 10.1016/j.envsci.2006.10.004

Meadows, D. (1999). Leverage Points: Places to Intervene in a System. Hartland, WI: The Sustainability Institute.

Meffe, G. K., Ehrenfeld, D., and Noss, R. F. (2006). Conservation biology at twenty. Conserv. Biol. 20, 595-596. doi: 10.1111/j.1523-1739.2006.00 441.x

Mezirow, J. (1991). Transformative Dimensions of Adult Learning. San Francisco, CA: Jossey-Bass.

Miller, C. A., and Wyborn, C. (2018). Co-production in global sustainability: histories and theories. Environ. Sci. Policy 113, 88-95. doi: 10.1016/J.Envsci.2018.01.016)

Mistry, J., and Berardi, A. (2016). Bridging indigenous and scientific knowledge. Science 352, 1274-1275. doi: 10.1126/science.aaf1160

Moon, K., and Blackman, D. (2016). A guide to understanding social science research for natural scientists. Conserv. Biol. 28, 1167-1177. doi: $10.1111 /$ cobi.12326

Moore, M.-L., Tjornbo, O., Enfors, E., Knapp, C., Hodbod, J., Baggio, J. A., et al. (2014). Studying the complexity of change: toward an analytical framework for understanding deliberate social-ecological transformations. Ecol. Soc. 19:54. doi: 10.5751/ES-06966-190454

Moser, S. (2016). Can science on transformation transform science? lessons from co-design. Curr. Opin. Environ. Sustain. 20, 106-115. doi: 10.1016/j.cosust.2016.10.007
Nyumba, T. O., Wilson, K., Derrick, C. J., and Mukherjee, N. (2018). The use of focus group discussion methodology: insights from two decades of application in conservation. Methods Ecol. Evol. 9, 20-32. doi: 10.1111/2041-210X.12860

O'Brien, K. (2012). Global environmental change ii: from adaptation to deliberate transformation. Prog. Hum. Geogr. 36, 667-676. doi: $10.1177 / 0309132511425767$

O'Brien, K. (2013). Global environmental change iii: closing the gap between knowledge and action. Prog. Hum. Geogr. 37, 587-596. doi: $10.1177 / 0309132512469589$

Olsson, P., Gunderson, L. H., Carpenter, S. R., Ryan, P., Lebel, L., Folke, C., et al. (2006). Shooting the rapids: navigating transitions to adaptive governance of social-ecological systems. Ecol. Soc.11:18. doi: 10.5751/ES-01595-110118

Olsson, P., Moore, M.-L., Westley, F. R., and Mccarthy, D. D. P. (2017). The concept of the anthropocene as a game-changer: a new context for social innovation and transformations to sustainability. Ecol. Soc. 22:31. doi: 10.5751/ES-09310-220231

O'Shaughnessy, S., and Krogman, N. T. (2011). Gender as contradiction: from dichotomies to diversity in natural resource extraction. J. Rural Stud. 27, 134-143. doi: 10.1016/j.jrurstud.2011.01.001

Ostrom, E. (1990). Governing the Commons: The Evolution of Institutions for Collective Action, Cambridge: Cambridge University Press. doi: $10.1017 /$ СBO9780511807763

Ostrom, E. (2009). A general framework for analyzing sustainability of socialecological systems. Science 325, 419-422. doi: 10.1126/science.1172133

Pahl-Wostl, C. (2009). A conceptual framework for analysing adaptive capacity and multi-level learning processes in resource governing regimes. Glob. Environ. Change 19, 354-365. doi: 10.1016/j.gloenvcha.2009.06.001

Pennington, D. D., Simpson, G. L., Mcconnell, M. S., Fair, J. M., and Baker, R. J. (2013). Transdisciplinary research, transformative learning, and transformative science. Bioscience 63, 564-573. doi: 10.1525/bio.2013.63.7.9

Pickering Sherman, K., and Sherman, R. (2010). "The indigenous stewardship model," in Indigenous Peoples and the Collaborative Stewardship of Nature, eds A. Ross, K. Pickering Sherman, J. G. Snodgrass, H. D. Delcore, and R. Sherman, (Walnut Creek, CA: Left Coast Press), 235-260.

Pohl, C., and Hirsch Hadorn, G. (2008). Methodological challenges of transdisciplinary research. Nat. Sci. Soc. 16, 111-121. doi: 10.1051/nss:2008035

Pohl, C., Rist, S., Zimmermann, A., Fry, P., Gurung, G. S., Schneider, F., et al. (2010). Researchers' roles in knowledge co-production: experience from sustainability research in Kenya, Switzerland, Bolivia and Nepal. Sci. Public Pol. 37, 267-281. doi: 10.3152/030234210X496628

Reed, M. S., Evely, A. C., Cundill, G., Fazey, I., Glass, J., Laing, A., et al. (2010). What is social learning? Ecol. Soc. 15:4. doi: 10.5751/ES-03564-1504r01

Reid, R. S. (2012). Savannas of Our Birth: People, Wildlife and Change in East Africa, Berkeley, CA: University of California Press. doi: 10.1525/9780520954076

Reid, R. S., Fernández-Giménez, M. E., and Galvin, K. A. (2014a). Dynamics and resilience of rangelands and pastoral peoples around the globe. Annu. Rev. Environ. Resour. 39, 217-242. doi: 10.1146/annurev-environ-020713-163329

Reid, R. S., Galvin, K. A., Knapp, E., Ogutu, J., and Kaelo, D. (2015). "Sustainability of the Serengeti-Mara ecosystem for wildlife and people," in Serengeti IV: Biodiversity, eds A. R. E. Sinclair and K. Metzger (Chicago, IL: University of Chicago Press).

Reid, R. S., Kaelo, D., Galvin, K. A., and Harmon, R. (2016a). "Pastoral wildlife conservancies in Kenya: a bottom-up revolution in conservation, balancing livelihoods and conservation?" in Proceedings of the International Rangelands Congress (Saskatoon, SK: International Rangelands Congress), 143-146.

Reid, R. S., Kaelo, D., Nkedianye, D. K., Kristjanson, P., Said, M. Y., Galvin, K. A., et al. (2014b). "The Mara-Serengeti ecosystem and greater Maasailand: building the role of local leaders, institutions, and communities," in Conservation Catalysts: The Academy as Nature's Agent, eds J. N. Levitt (Cambridge, MA: Lincoln Institute of Land Policy).

Reid, R. S., Nkedianye, D., Said, M. Y., Kaelo, D., Neselle, M., Makui, O., et al. (2016b). "Evolution of models to support community and policy action with science: balancing pastoral livelihoods and wildlife conservation in Savannas of East Africa," in Proc. Natl. Acad. Sci. U.S.A. 113, 4579-4584. doi: 10.1073/pnas.0900313106

Reyers, B., Roux, D. J., Cowling, R. M., Ginsburg, A. E., Nel, J. L., and O’farrell, P. (2010). Conservation planning as a transdisciplinary process. Conserv. Biol. 24, 957-965. doi: 10.1111/j.1523-1739.2010.01497.x 
Reynolds, J. F., Smith, D. M., Lambin, E. F., Turner, B. L., 2nd, Mortimore, M., Batterbury, S. P., et al. (2007). Global desertification: building a science for dryland development. Science 316, 847-851. doi: 10.1126/science.1131634

Robinson, M., and Kassam, K.-A. (1998). Sami Potatoes: Living With Reindeer and Perestroika. Calgary, AB: Bayeux Arts, Translated and Published in Russian.

Robinson, S., Whitton, M., Biber-Klemm, S., and Muzofirshoev, N. (2010). The impact of land-reform legislation on pasture tenure in Gorno-Badakhshan: from common resource to private property? Mt. Res. Dev. 30, 4-13. doi: 10.1659/MRD-JOURNAL-D-09-00011.1

Rocheleau, D. E. (1995). Gender and biodiversity - a feminist political ecology perspective. Ids Bull. Inst. Dev. Stud. 26, 9-16. doi: 10.1111/j.1759-5436.1995.mp26001002.x

Sachs, C. (1996). Gendered Fields: Rural Women, Agriculture, and Environment, Boulder, CO: Westview Press. doi: 10.1007/978-1-349-24611-3_21

Sachs, C. E., Barbercheck, M. E., Brasier, K. J., Kiernan, N. E., and Terman, A. R. (2016). The Rise of Women Farmers and Sustainable Agriculture. Iowa, IA: University of Iowa Press. doi: 10.2307/j.ctt20p57gr

Sayre, N. F., Mcallister, R. R. J., Bestelmeyer, B. T., Moritz, M., and Turner, M. D. (2013). Earth stewardship of rangelands: coping with ecological, economic, and political marginality. Front. Ecol. Environ. 11, 348-354. doi: 10.1890/120333

Schuttenberg, H. Z., and Guth, H. K. (2015). Seeking our shared wisdom: a framework for understanding knowledge coproduction and coproductive capacities. Ecol. Soc. 20:15. doi: 10.5751/ES-07038-200115

Seidl, R., Brand, F. S., Stauffacher, M., Krutli, P., Le, Q. B., Sporri, A., et al. (2013). Science with society in the Anthropocene. Ambio 42, 5-12. doi: $10.1007 /$ s13280-012-0363-5

Shackleton, C. M., Willis, T. J., Brown, K., and Polunin, N. V. C. (2010). Reflecting on the next generation of models for community-based natural resources management. Environ. Conserv. 37, 1-4. doi: 10.1017/S0376892910000366

Shirk, J. L., Ballard, H. L., Wilderman, C. C., Phillips, T., Wiggins, A., Jordan, R., et al. (2012). Public participation in scientific research: a framework for deliberate design. Ecol. Soc. 17:29. doi: 10.5751/ES-04705-170229

Smith, L. T. (2002). Decolonizing Methodologies: Research and Indigenous Peoples. London: Zed Books.

Susskind, L., Camacho, A. E., and Schenk, T. (2012). A critical assessment of collaborative adaptive management in practice. J. Appl. Ecol. 49, 47-51. doi: 10.1111/j.1365-2664.2011.02070.x

Tengo, M., Brondizio, E. S., Elmqvist, T., Malmer, P., and Spierenburg, M. (2014). Connecting diverse knowledge systems for enhanced ecosystem governance: the multiple evidence base approach. Ambio 43, 579-591. doi: $10.1007 /$ s13280-014-0501-3

Thompson, J. L. (2009). Building collective communication competence in interdisciplinary research teams. J. Appl. Commun. Res. 37, 278-297. doi: 10.1080/00909880903025911

Tschakert, P., and Dietrich, K. A. (2010). Anticipatory learning for climate change adaptation and resilience. Ecol. Soc. 15:11. doi: 10.5751/ES-03335-150211

Tuck, E., and Yang, K. W. (2012). Decolonization is not a metaphor. Decolonization Indigeneity Educ Soc. 1, 1-40

Ulambayar, T., and Fernández-Giménez, M. E. (2019). How communitybased rangeland management achieves positive social outcomes in Mongolia: a moderated mediation analysis. Land Use Policy 82, 93-104. doi: 10.1016/j.landusepol.2018.11.008

Ulambayar, T., Fernández-Giménez, M. E., Batkhishig, B., and Batbuyan, B. (2017). Social outcomes of community-based rangeland management in Mongolian steppe ecosystems. Conserv. Lett. 10, 317-327. doi: 10.1111/conl.12267

UNDP (2019). Human Development Index, New York, NY: UNDP.

Uphoff, N. (1986). Improving International Irrigation Management With Farmer Participation: Getting the Process Right. New York, NY: Westview Press.

van Kerkhoff, L. (2014). Developing integrative research for sustainability science through a complexity principles-based approach. Sustain. Sci. 9, 142-155. doi: $10.1007 / \mathrm{s} 11625-013-0203-y$ van Kerkhoff, L., and Lebel, L. (2006). Linking knowledge and action for sustainable development. Annu. Rev. Environ. Resour. 31, 445-477. doi: 10.1146/annurev.energy.31.102405.170850

Walker, B., Holling, C. S., Carpenter, S. R., and Kinzig, A. (2004). Resilience, adaptability and transformability in social-ecological systems. Ecol. Soc. 9:5. doi: 10.5751/ES-00650-090205

Walter, A. I., Helgenberger, S., Wiek, A., and Scholz, R. W. (2007). Measuring societal effects of transdisciplinary research projects: design and application of an evaluation method. Eval. Prog. Plan. 30, 325-338. doi: 10.1016/j.evalprogplan.2007.08.002

Westley, F., Olsson, P., Folke, C., Homer-Dixon, T., Vredenburg, H., Loorbach, D., et al. (2011). Tipping towards sustainability: emerging pathways of transformation. Ambio 40, 762-780. doi: 10.1007/s13280-011-0186-9

Westley, F. R., Mcgowan, K. A., and Tjornbo, O. (2017). The Evolution of Social Innovation. Northampton, MA: Edward Elgar Publishing. doi: $10.4337 / 9781786431158$

Westley, F. R., Tjornbo, O., Schultz, L., Olsson, P., Folke, C., Crona, B., et al. (2013). A theory of transformative agency in linked social-ecological systems. Ecol. Soc. 18:27. doi: 10.5751/ES-05072-180327

Westley, F. R., Zimmerman, B., and Patton, M. Q. (2006). Getting to Maybe: How the World is Changed Toronto. Ontario, TO: Vintage Canada.

Whatmore, S. (1991). Farming Women: Gender, Work and Family Enterprise. London: Macmillan. doi: 10.1007/978-1-349-11615-7

Wiek, A., Talwar, S., O'shea, M., and Robinson, J. (2014). Toward a methodological scheme for capturing societal effects of participatory sustainability research. Res. Eval. 23, 117-132. doi: 10.1093/reseval/rvt031

Willow, A. (2015). Collaborative conservation and contexts of resistance: new (and enduring) strategies for survival. Am. Indian Cult. Res. J. 39, 29-52. doi: 10.17953/aicrj.39.2.willow

Wilmer, H., Derner, J. D., Fernández-Giménez, M. E., Briske, D. D., Augustine, D. J., Porensky, L. M., et al. (2018). Collaborative adaptive rangeland management fosters management-science partnerships. Rangeland Ecol. Manage. 71, 646-657. doi: 10.1016/j.rama.2017.07.008

Wilmer, H., Porensky, L. M., Fernández-Giménez, M. E., Derner, J. D., Augustine, D. J., J.P., et al. (2019). Community-engaged research builds a natureculture of hope on North American Great Plains rangelands. Soc. Sci. 8:22. doi: 10.3390/socsci8010022

Wilson, S. M., Bradley, E. H., and Neudecker, G. A. (2017). Learning to live with wolves: community-based conservation in the Blackfoot Valley of Montana. Hum. Wildlife Inter. 11, 245-257. doi: 10.26077/bf8e-6f56

Wyborn, C. (2015). Co-productive governance: a relational framework for adaptive governance. Glob. Environ. Change Hum. Policy Dimen. 30, 56-67. doi: 10.1016/j.gloenvcha.2014.10.009

Wyborn, C., Datta, A., Montana, J., Ryan, M., Leith, P., Chaffin, B., et al. (2019). Co-producing sustainability: reordering the governance of science, policy, and practice. Ann. Rev. Environ. Resour. 44, 319-346. doi: 10.1146/annurev-environ-101718-033103

Conflict of Interest: The authors declare that the research was conducted in the absence of any commercial or financial relationships that could be construed as a potential conflict of interest.

Copyright (C) 2021 Reid, Fernández-Giménez, Wilmer, Pickering, Kassam, Yasin, Porensky, Derner, Nkedianye, Jamsranjav, Jamiyansharav, Ulambayar, OterosRozas, Ravera, Bulbulshoev, Kaziev and Knapp. This is an open-access article distributed under the terms of the Creative Commons Attribution License (CC BY). The use, distribution or reproduction in other forums is permitted, provided the original author(s) and the copyright owner(s) are credited and that the original publication in this journal is cited, in accordance with accepted academic practice. No use, distribution or reproduction is permitted which does not comply with these terms. 